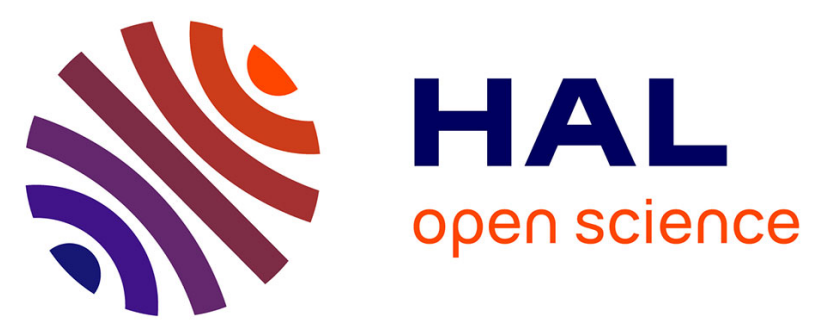

\title{
A comprehensive study of the toxicity of natural multi-contaminated sediments: New insights brought by the use of a combined approach using the medaka embryo-larval assay and physico-chemical analyses
}

Iris Barjhoux, Christelle Clérandeau, Karyn Le Menach, Pierre Anschutz, Patrice Gonzalez, Hélène Budzinski, Bénédicte Morin, Magalie Baudrimont, Jérôme Cachot

\section{- To cite this version:}

Iris Barjhoux, Christelle Clérandeau, Karyn Le Menach, Pierre Anschutz, Patrice Gonzalez, et al.. A comprehensive study of the toxicity of natural multi-contaminated sediments: New insights brought by the use of a combined approach using the medaka embryo-larval assay and physico-chemical analyses. Ecotoxicology and Environmental Safety, 2017, 142, pp.509-521. 10.1016/j.ecoenv.2017.04.059 . hal02153604

\author{
HAL Id: hal-02153604 \\ https://hal.science/hal-02153604
}

Submitted on 4 May 2020

HAL is a multi-disciplinary open access archive for the deposit and dissemination of scientific research documents, whether they are published or not. The documents may come from teaching and research institutions in France or abroad, or from public or private research centers.
L'archive ouverte pluridisciplinaire HAL, est destinée au dépôt et à la diffusion de documents scientifiques de niveau recherche, publiés ou non, émanant des établissements d'enseignement et de recherche français ou étrangers, des laboratoires publics ou privés. 


\title{
A comprehensive study of the toxicity of natural multi-
}

\section{contaminated sediments: new insights brought by the use of a}

\section{combined approach using the Medaka embryo-larval assay}

\section{and physico-chemical analyses}

\author{
Iris Barjhoux ${ }^{\otimes, 1}$, Christelle Clérandeau, Karyn Le Menach, Pierre Anschutz, Patrice \\ Gonzalez, Hélène Budzinski, Bénédicte Morin, Magalie Baudrimont and Jérôme Cachot
}

Univ. Bordeaux, EPOC UMR CNRS 5805, allée Geoffroy Saint-Hilaire, 33615 Pessac Cedex, France

\section{E-mail contacts:}

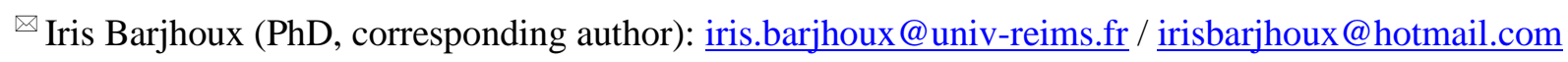
(permanent). Christelle Clérandeau (MEnvSc): c.clerandeau@epoc.u-bordeaux1.fr. Karyn Le Menach (MEnvSc): k.lemenach@epoc.u-bordeaux1.fr. Pierre Anschutz (Prof): p.anschutz@epoc.ubordeaux1.fr. Patrice Gonzalez (PhD): p.gonzalez@epoc.u-bordeaux1.fr. Hélène Budzinski (RD PhD) : h.budzinski@epoc.u-bordeaux1.fr. Bénédicte Morin (PhD): b.morin@epoc.u-bordeaux 1.fr. Magalie Baudrimont (Prof.): m.baudrimont@epoc.u-bordeaux1.fr. Jérôme Cachot (Prof.): jerome.cachot@u-bordeaux.fr.

\footnotetext{
${ }^{1}$ Present adress: Univ. Reims Champagne-Ardenne, UMR-I 02 INERIS-URCA-ULH SEBIO, Moulin de la Housse, BP 1039, 51687 Reims Cedex 2, France. Phone: +33 (0)326913719. Fax: +33 (0)326913342
} 


\section{Abstract}

2 Sediment compartment is a long term sink for pollutants and a secondary source of

3 contamination for aquatic species. The abiotic factors controlling the bioavailability and thus

4 the toxicity of complex mixtures of pollutants accumulated in sediments are poorly

5 documented. To highlight the different factors influencing sediment toxicity, we identified

6 and analyzed the physico-chemical properties, micro-pollutant contents, and toxicity level of

7 six contrasted sediments in the Lot-Garonne continuum. Sediment toxicity was evaluated using the recently described Japanese medaka (Oryzias latipes) embryo-larval assay with direct exposure to whole sediment (MELAc). Multiple toxicity endpoints including embryotoxicity, developmental defects and DNA damage were analyzed in exposed embryos. Chemical analyses revealed significant variations in the nature and contamination profile of sediments, mainly impacted by metallic trace elements and, unexpectedly, polycyclic aromatic hydrocarbons. Exposure to sediments induced different toxic impacts on medaka early life stages when compared with the reference site. Principal component analysis showed that the toxic responses following exposure to sediments from the Lot River and its tributary were associated with micro-pollutant contamination: biometric measurements, hatching success, genotoxicity, craniofacial deformities and yolk sac malabsorption were specifically correlated to metallic and organic contaminants. Conversely, the main biological responses following exposure to the Garonne River sediments were more likely related to their physico-

\footnotetext{
Abbreviations: Bdx, Bordeaux station; Bo, Bouillac station; DBT, dibenzothiophene; dpf, days post-fertilization; dph, days post-hatching; dw, dry weight; ELS, early life stages; ERS, egg rearing solution; GC-ECD, gas chromatography coupled to electron capture detection; GCMS, gas chromatography coupled to mass spectrometry; Jo, Joanis station; LR, La Réole station; LT, Le Temple station; MELAc, Medaka Embryo-Larval Assay in sediment-contact; MPhe, methylphenanthrenes; Mrc, Marcenac station; MTE, metallic trace elements; PAHs, polycyclic aromatic hydrocarbons; PBDEs, polybrominated diphenyl ethers; PCA, principal component analysis; PCBs, polychlorobiphenyls; PEC, probable effect concentration; POC, particulate organic carbon; POPs, persistent organic pollutants; qPEC, probable effect concentration quotients; SD, standard deviation; SI, supporting information; TEC, threshold effect concentration.
} 
chemical properties than to their contamination level. Time to hatch, cardiovascular injuries and spinal deformities were correlated to organic matter content, fine particles and dissolved oxygen levels. These results emphasize the necessity of combining physico-chemical analysis of sediment with toxicity assessment to accurately evaluate the environmental risks associated with sediment contamination.

26 Keywords: sediment toxicity, pollutant mixture, physico-chemical properties, fish embryolarval assay, multivariate statistics. 


\section{Introduction}

As the final receptacle of pollutants from various origins (industrial, urban and agricultural) and their ability to accumulate substances such as persistent organic pollutants (POPs) and metallic trace elements (MTE), sediments are considered as both a sink and a long-term source of contamination for aquatic organisms (Burton Jr, 1991). Such contamination could threaten not only benthic organisms living on direct contact to sediment but also the entire aquatic ecosystem and finally human health via bioaccumulation, trophic transfer and/or drinking water (Fent, 2004). The evaluation of sediment toxicity is thus of major concern in environmental risk assessment strategies. While integrated procedures combining chemical analyses and biological responses are widely recommended (Ahlf et al., 2002), there is still no system of universal toxicity bioassay(s) capable of predicting the potential hazard of contaminated sediments. Because this particular matrix is very complex to analyze, several test phases have been used for sediment toxicity testing as, for instance, extractable pollutants and pore water (Burton Jr, 1991). However, whole sediment exposure is generally considered the most realistic and integrative method to mimic contamination of organisms in situ as the uptake route (including sediment-contact and aqueous phase exposure) is very similar to that found in environmental conditions, taking sediment characteristics and physico-chemical properties governing pollutant bioavailability into account (Hollert et al., 2003; Kosmehl et al., 2006).

In conventional ecotoxicity testing strategies, fish represent an indispensable component of integrated toxicity assessments because of their high sensitivity to contaminants, their critical role in the aquatic food chain and their socio-economic importance (Lammer et al., 2009). In the light of European regulations on the protection of animals used for scientific purpose (EC, 2010), fish early life stages (ELS) bioassays have gained interest in environmental risk assessments and (eco)toxicological evaluations. Indeed, their higher sensitivity to a wide 
range of chemicals when compared with adult or juvenile stages (Hutchinson et al., 1998), their ecological relevance (e.g. recruitment, population wellness) (Burton Jr, 1991; Cao et al., 2009) and the possibility they offer to perform small-scale, high-throughput analyses with an excellent correlation to conventional in vivo testing (Lammer et al., 2009) make fish ELS a promising tool to replace traditional acute fish tests (Braunbeck et al., 2005). As a result, fish ELS-based bioassays found their way into the laboratories not only to test chemical (eco)toxicity, but also to assess the hazard of environmental samples such as sediments (Hallare et al., 2005; Hollert et al., 2003; Kosmehl et al., 2008, 2006). These studies investigated embryotoxic, teratogenic and genotoxic potencies of sediments in zebrafish ELS demonstrating the suitability of such whole sediment-contact embryo-larval assays for natural sediment testing as it enables to evaluate the impacts of the sole bioavailable fraction of particle-bound pollutants from complex environmental matrices containing a mixture of a multitude of chemicals. Japanese medaka embryos offer similar practical advantages to zebrafish embryos for developmental toxicity testing, but its longer development time in the egg provides the possibility to extend the duration of embryonic exposure to 9-10 days at $26{ }^{\circ} \mathrm{C}$ (as opposed to $48-72 \mathrm{~h}$ for zebrafish), which can mimic a more chronic exposure to contaminants (Barjhoux et al., 2012).

The Medaka Embryo-Larval Assay in sediment-contact (MELAc) was developed in our laboratory. It consisted in an incubation of Japanese medaka (Oryzias latipes) embryos at the surface of sediment for the whole duration of the embryonic phase. As recommended, several non-invasive lethal and sublethal endpoints of embryotoxicity and teratogenicity are analyzed during the bioassay. Additional genotoxicity assessment is also performed on 2-days posthatching (dph) larvae using the Comet assay. This procedure proved its applicability and its relevance for hydrophobic substances, MTE and sediment organic extract toxicity testing (Barjhoux et al., 2014, 2012; Cachot et al., 2007; Vicquelin et al., 2011). In the present study, 
we propose an application of the MELAc to the evaluation of whole raw sediment (i.e. with no prior extraction procedures) from a multi-contaminated environment: the Lot-Garonne continuum (South West of France).

This area is highly impacted by historical polymetallic pollution, first highlighted in the early 1970s by the National Observation Network, and characterized by very high Cd bioaccumulation in bivalves collected downstream, in the Gironde estuary, revealing it was in fact the most contaminated along the European coastline. The main source of $\mathrm{Cd}$ was identified in the upper part of the Lot River (Latouche, 1992), in a small Lot tributary (the Riou-Mort River) draining the waste area of a now-abandoned factory previously specializing in zinc ore treatment, which had been active for over a century in the Decazeville industrial basin. Although mining activities stopped for several decades and remediation procedures are in progress, the Lot-Garonne-Gironde fluvial-estuarine system remains clearly impacted by MTE such as $\mathrm{Cd}, \mathrm{Pb}, \mathrm{Cu}$ and $\mathrm{Zn}$ (Audry et al., 2004). These MTE are mainly transported in the particulate phase along the Lot-Garonne-Gironde continuum and constitute the major metallic inputs in the estuary (Audry et al., 2004). Sediments within the Lot-Garonne system represent a real storage compartment for MTE that can be remobilized in the water column during natural (flood, storm) or anthropogenic (dredging, dam flush) events and salinity gradient rising in the Gironde estuary (Audry et al., 2010). While the effects of the polymetallic contamination of the water column have been investigated in several aquatic organisms such as diatoms, bivalves and fish (e.g. Arini et al., 2012, 2011; Orieux et al., 2011), to our knowledge there is no study directly investigating the toxicity of sediments from this area.

The present study aimed to assess the embryotoxicity, teratogenicity and genotoxicity of six multi-contaminated sediments from the Lot-Garonne system using the MELAc. In parallel, a comprehensive characterization of sediments was carried out including MTE and POP 
contaminant levels and physico-chemical properties. Correlation and principal component analyses were conducted to investigate the possible interrelationships between physicochemical and contamination parameters between themselves as well as with biological responses. Finally, a discussion on the toxic potential of the studied sediments and the relevance of the considered biomarkers is proposed.

\section{Material and Methods}

\subsection{Study sites and sample collection}

Six stations were selected along the polymetallic gradient of the Lot-Garonne continuum in South-West France (Fig. 1). The Marcenac (Mrc) station (44³5'53.5" N, 2¹4'29.4" E) was located on the right bank of the Lot River, above its confluence with the Riou-Mort River. This sediment was used as the reference, as Marcenac is considered as a pristine site for MTE contamination in the Lot-Garonne-Gironde continuum (Audry et al., 2010). Moreover, previous work in our laboratory already demonstrated that Marcenac sediment was an adequate substrate for medaka embryonic development (Barjhoux et al., 2012). Joanis (Jo) station (443 $\left.33^{\prime} 56.9^{\prime \prime} \mathrm{N}, 2^{\circ} 12^{\prime} 41.1^{\prime \prime} \mathrm{E}\right)$ was located on the banks of the Riou-Mort River, about $2 \mathrm{~km}$ downstream from the ancient zinc factory. At this site, MTE contamination is expected to be the highest of all selected sampling sites (Audry et al., 2004). Bouillac (Bo) station $\left(44^{\circ} 34^{\prime} 54.3^{\prime \prime} \mathrm{N}, 2^{\circ} 12^{\prime} 02.8^{\prime \prime} \mathrm{E}\right)$ is situated on the Lot River at about $20 \mathrm{~m}$ downstream from its confluence with the Riou-Mort, is representative of the MTE discharge in the Lot River system from the old mining activities in the industrial basin of Decazeville. Still on the Lot River, Le Temple (LT) station $\left(44^{\circ} 23^{\prime} 43.3^{\prime \prime} \mathrm{N} 0^{\circ} 32^{\prime} 33.1^{\prime \prime E}\right)$, located at around $15 \mathrm{~km}$ from the confluence with the Garonne River, thus integrating the outlet of the Lot River watershed before it reaches the Garonne River (Audry et al., 2010, 2004). 
128 Finally, two sites were selected on the Garonne River banks: La Réole (LR) station

$129\left(44^{\circ} 34^{\prime} 41.1^{\prime \prime} \mathrm{N}, 0^{\circ} 02^{\prime} 01.6^{\prime \prime} \mathrm{W}\right)$, at around $50 \mathrm{~km}$ downstream from the junction of the Lot and

130 Garonne Rivers and located just upstream of the tidal limit; and Bordeaux (Bdx) station

$131 \quad\left(44^{\circ} 51^{\prime} 02.0^{\prime \prime} \mathrm{N}, 0^{\circ} 33^{\prime} 46.7^{\prime \prime} \mathrm{W}\right)$, located in the fluvial part of the Gironde Estuary, which

132 integrates both polymetallic contamination from the Lot River and anthropogenic pollution

133 from the Bordeaux conurbation ( 1,000,000 inhabitants) (Schäfer et al., 2009).

134 All the sediments were sampled in April 2011 with the exception of Marcenac sediment,

135 which was collected during a previous sampling campaign in March 2009. At each sampling

136 station, only the superficial layer $(0-2 \mathrm{~cm})$ of sediment was collected. Samples were packed

137 in aluminum boxes and cool-transported to the laboratory where they were immediately

138 stored at $-20{ }^{\circ} \mathrm{C}$. Sediments were kept at $4{ }^{\circ} \mathrm{C}$ overnight for slow defrost. An aliquot was

139 sieved using a 1-mm mesh to eliminate debris and homogenized prior to use in the bioassay

140 and chemical analyses. Another subsample was used to extract pore water. The sediment was

141 put in a $0.2 \mu \mathrm{m}$ VIVASPIN20 centrifuge vial. Pore waters were extracted by centrifugation at

$1424000 \mathrm{rpm}$ for $20 \mathrm{~min}$.

\subsection{Physico-chemical characterization and contamination levels of sediments}

Physical and chemical analyses were conducted on sediment from each sampling stations to determine their natural characteristics (Table 1).

The grain-size distribution was measured using a Malvern laser diffraction particle size analyzer. Particulate organic carbon (POC) content was determined on freeze-dried

149 homogenized sediment by infrared spectroscopy (LECO C-S analyzer) after removal of ammonium $\left(\mathrm{NH}_{4}\right)$ was analyzed in pore water using the phenol reaction followed by 
protocols used for the above-mentioned analyses are described by Vicquelin et al. (2011).

MTE analysis was performed on each sediment ( $0.5 \mathrm{~g}$ dry wet of sediment, $\mathrm{dw}$ ) after a up to $25 \mathrm{~mL}$ with Milli-Q water. Ten MTE including $\mathrm{Ag}, \mathrm{As}, \mathrm{Cd}, \mathrm{Co}, \mathrm{Cr}, \mathrm{Cu}, \mathrm{Mn}, \mathrm{Ni}, \mathrm{Pb}$ and Zn were measured by ICP-MS (4500 Series, Agilent Technologies, Wilmington, DE, USA), using external calibration. A $1 \mathrm{~g} / \mathrm{L}$ multi-elemental solution was used to prepare the standard solutions. Rhodium was used as an internal standard to evaluate the instrumental drift. The accuracy of the determination procedure was assessed by analysis of the standard reference PACS2 (NRCC, CNRC, marine sediment). The concentrations measured for the standard sediment were consistent with the certified values. $\mathrm{Hg}$ was also analyzed in sediment using an Automated Mercury Analyzer (LECO, AMA-254) as previously described by Baudrimont et al. (2005). The analytical results were quality-checked by analyzing international certified TORT-2 reference materials (NRCC, CNRC, lobster hepatopancreas) after each set of samples. Measured concentrations were consistently within the certified ranges.

Organic contaminants were quantified in freeze-dried sediments from each station after homogenization and a micro-waved extraction step using dichloromethane. Detailed procedures concerning extraction, purification and analysis of organic compounds have been widely described in previous works from our laboratory (Devier et al., 2005; Tapie et al., 2008). Briefly, organic extracts were purified on alumina micro-columns containing activated copper. A second purification step took place on acidified silica micro-column during which polycyclic aromatic hydrocarbons (PAHs) and organohalogenated compounds were co-eluted using a mixture of pentane and dichloromethane $(90 / 10, v / v)$. The final extract was reconcentrated and divided in two aliquots for PAH and organohalogen analysis. Quantification of PAHs (listed in Table 1), including 21 individual PAHs, 5 methylphenanthrenes (MPhe) 
177 and dibenzothiophene (DBT), was performed by gas chromatography coupled to mass

178

179

180

181

182

183

184

185

186

187

188

189

190

191

192 spectrometry (GC-MS) whereas organohalogen content (listed in Table 1), including 8 polychlorobiphenyls (PCBs) congeners, 4 polybrominated diphenyl ethers (PBDEs) and lindane, was analyzed by gas chromatography coupled to electron capture detection (GCECD).

The quality of the analytical procedure was systematically controlled in each batch of analysis. Specific PAH and organohalogen standards were gravimetrically added in one hand, prior to extraction as internal standards and others prior to GC-MS or GC-ECD analysis as syringe standards, on the other hand. An extraction blank was also added with each series of extractions. To test the accuracy and validity of the quantification method, standard solutions (for PAHs and organohalogens separately) of compounds to be quantified in mixture with the related internal standards are regularly run on the GC-MS and GC-ECD systems.

\begin{tabular}{|c|c|c|c|c|c|c|c|c|}
\hline & Marcenac & Bordeaux & La Réole & Le Temple & Bouillac & Joanis & TEC $^{a}$ & $\mathrm{PEC}^{\mathrm{a}}$ \\
\hline $\mathrm{D}(0.50)(\mu \mathrm{m})$ & 151 & 27.0 & 32.1 & 392 & 274 & 325 & & \\
\hline Fine particles $(<63 \mu \mathrm{m})(\%)$ & 9.6 & 81.0 & 71.9 & 4.6 & 19.3 & 11.3 & & \\
\hline POC (\%) & 0.1 & 1.2 & 2.1 & 0.1 & 0.8 & 0.3 & & \\
\hline $\mathrm{NH}_{4}(\mu \mathrm{M})$ & 24.9 & 290 & 743 & 114 & 424 & 164 & & \\
\hline
\end{tabular}

\section{Metallic trace elements (MTE) $(\mu g / g d w)$}

$\begin{array}{lllllllll}\text { Ag } & 0.0 & 0.1 & 0.1 & 0.0 & 1.0 & 2.4 & - & - \\ \text { As } & 17.5 & 8.9 & 10.7 & 3.0 & 42.6 & 28.5 & 9.8 & 33.0 \\ \text { Cd } & 0.1 & 1.3 & 1.5 & 0.4 & 17.9 & 14.6 & 1.0 & 5.0 \\ \text { Co } & 5.6 & 8.9 & 8.3 & 5.1 & 10.4 & 9.8 & - & -\end{array}$




$\begin{array}{lllllllll}\mathrm{Cr} & 10.0 & 24.1 & 23.7 & 10.2 & 11.3 & 23.2 & 43.4 & 111 \\ \mathrm{Cu} & 6.2 & 16.5 & 20.1 & 4.1 & 78.7 & 96.7 & 31.6 & 149 \\ \mathrm{Mn} & 261 & 535 & 649 & 183 & 843 & 883 & - & - \\ \mathrm{Ni} & 9.5 & 16.6 & 16.9 & 16.2 & 22.8 & 17.5 & 22.7 & 48.6 \\ \mathrm{~Pb} & 12.5 & 30.2 & 25.8 & 3.9 & 273 & 318 & 35.8 & 128 \\ \mathrm{Zn} & 35.0 & 103 & 116 & 16.8 & 2,041 & 2,293 & 121 & 459 \\ \mathrm{Hg} & 0.05 & 0.03 & 0.16 & 0.08 & 0.09 & 0.25 & 0.18 & 1.06 \\ \Sigma \mathrm{MTE} & 357 & 745 & 872 & 243 & 3,342 & 3,687 & & \end{array}$

Organic contaminants (OC) (ng/g dw)

\begin{tabular}{|c|c|c|c|c|c|c|c|c|}
\hline$\Sigma \mathrm{LPAHs}^{\mathrm{b}}$ & 3.2 & 85.4 & 127 & 2,603 & 214 & 15,649 & & \\
\hline$\Sigma \mathrm{HPAHS}^{\mathrm{c}}$ & 9.4 & 1,114 & 788 & 21,585 & 814 & 9,352 & & \\
\hline$\Sigma \mathrm{MPhe}^{\mathrm{d}}$ & 1.7 & 39.3 & 46.2 & 984 & 75.5 & 849 & & \\
\hline$\Sigma \mathrm{PAHs}^{\mathrm{e}}$ & 13.8 & 1,239 & 960 & 25,173 & 1,103 & 25,850 & 1,610 & 22,800 \\
\hline DBT & 0.3 & 3.6 & 4.5 & 113 & 7.0 & 309 & & \\
\hline Lindane & 0.1 & 0.1 & 0.1 & $<\mathrm{dl}$ & $<\mathrm{dl}$ & $<\mathrm{dl}$ & 2.37 & 4.99 \\
\hline$\Sigma \mathrm{PCBs}^{\mathrm{f}}$ & 1.0 & 8.9 & 14.4 & 0.8 & 3.3 & 3.7 & 59.8 & 676 \\
\hline$\Sigma$ PBDEs $^{g}$ & $<\mathrm{dl}$ & 0.1 & $<\mathrm{dl}$ & $<\mathrm{dl}$ & 0.1 & 0.4 & & \\
\hline$\Sigma \mathrm{OHCs}^{h}$ & 1.1 & 9.0 & 14.4 & 0.8 & 3.4 & 4.1 & & \\
\hline$\Sigma \mathrm{OC}^{\mathrm{i}}$ & 15.2 & 1,252 & 979 & 25,286 & 1,114 & 26,163 & & \\
\hline Mean qPEC $1^{j}$ & 0.10 & 0.16 & 0.18 & 0.18 & 1.27 & 1.38 & & \\
\hline Mean qPEC2 $2^{j}$ & 0.06 & 0.11 & 0.13 & 0.68 & 0.74 & 1.88 & & \\
\hline $\begin{array}{l}\text { Mean qPEC-based } \\
\text { rankingk }^{k}\end{array}$ & \#1 & \#2 & \#3 & $\# 4$ & \#5 & \#6 & & \\
\hline MELAc-based rankingl & $\begin{array}{l}\# 1(0 ; \\
\text { refere }\end{array}$ & \#3 (4) & \#5 (7) & \#3 (4) & \#2 (3) & \#6 (11) & & \\
\hline
\end{tabular}


a values taken from MacDonald et al. (2000)

${ }^{b}$ sum of low molecular weight PAHs (LPAHs; three or fewer aromatic rings) includes naphthalene, acenaphthene, acenaphthylene, fluorene, phenanthrene and anthracene c sum of high molecular weight PAHs (HPAHs; four or more aromatic rings) includes fluoranthene, pyrene, benzo[a]anthracene, chrysene, triphenylene, benzo[b]fluoranthene, benzo[k]fluoranthene, benzo[j]fluoranthene, benzo[e]pyrene, benzo[a]pyrene, perylene, indeno[1,2,3-c,d]pyrene, dibenzo[a,h]anthracene, dibenzo[a,c]anthracene and benzo[g,h,i]perylene d sum of methylphenanthrenes (MPhe) includes 1-, 2-, 3-, and 9-methylphenantrene and 1methylanthracene e sum of PAHs includes $\Sigma$ LPAHs, $\Sigma$ HPAHs and $\Sigma$ MPhe

${ }^{k}$ sediment ranking according to their calculated mean QPEC values. Note that similar ranking of sediments was obtained using mean $\mathrm{qPEC} 1$ or mean $\mathrm{qPEC} 2$ values ' sediment ranking based on the number of significant sublethal effects (indicated in brackets) recorded in each treatment using the MELAc $\mathrm{D}(0.50)$, median particle size; $d w$, dry weight of sediment; DBT, dibenzothiophene; MPhe, methylphenanthrenes; PAHs, polyaromatic hydrocarbons; PBDEs, polybrominated diphenyl ethers; PCBs, polychlorinated biphenyls; PEC, probable effect concentration; mean qPEC1, mean PEC quotient value calculated for each sediment using $\Sigma \mathrm{PAH}$ concentrations; mean qPEC2, mean PEC quotient value calculated for each sediment using individual PAH concentrations; TEC, threshold effect concentration.

\subsection{Medaka embryo-larval assay with sediment-contact exposure (MELAc)}

Toxicity assessment of six sediments from the Lot-Garonne system was performed using the

Medaka embryo-larval assay with a direct sediment-contact exposure (Barjhoux et al., 2012; 
mm-diameter plastic Petri dish and immerged by adding $2 \mathrm{ml}$ of egg rearing solution (ERS; 17.11 mM NaCl, $0.4 \mathrm{mM} \mathrm{KCl,} 0.36 \mathrm{mM} \mathrm{CaCl}_{2} ; 1.36 \mathrm{mM} \mathrm{MgSO}_{4}, \mathrm{pH}$ 7.0). The resulting system was then maintained at $26^{\circ} \mathrm{C}$ for a $4-5 \mathrm{~h}$ equilibration period before the beginning of the experiment.

Japanese medaka (O. latipes) embryos of the CAB strain were purchased from GIS Amagen (Gif-sur-Yvette, France) and received 24 hours post-fertilization. Upon receipt, healthiness and developmental synchronism of 1 day post-fertilization (dpf) embryos were checked using a stereomicroscope (Leica MZ75, Leica Microsystems) and cold-light source (Intralux® 4100, Volpi AG). Immediately after sorting, embryos (27 per replicate and three replicates per treatment) were placed on a Nytex ${ }^{\circledR}$ mesh (mesh opening $1000 \mu \mathrm{m}$, Sefar Filtration Inc.) which was then slightly sunk into the sediment to ensure a good contact between eggs and particles. The level of ERS buffer was adjusted to ensure complete immersion of embryos in the medium. The buffer was then completely renewed every day. Dissolved oxygen was also measured daily throughout the 10-day exposure period at the water-sediment interface using a Clark-type sensor equipped with a guard cathode (Unisense, Aarhus, DK) and connected to a high sensitivity picoammeter (PA2000, Unisense) as detailed by Vicquelin et al. (2011).

As described by Barjhoux et al. (2012), embryos were kept exposed to sediments until hatching peak (10 dpf) in the reference treatment (Marcenac). Afterwards, unhatched embryos were transferred to new Petri dishes with $3 \mathrm{~mL}$ of clean ERS. Similarly, newly hatched larvae were transferred in $50 \mathrm{~mL}$ of clean stalling water $(1 / 3 \mathrm{v} / \mathrm{v}$ of dechlorinated tap water and osmosed water, $26{ }^{\circ} \mathrm{C}, \mathrm{pH}$ 7.5, $53.4 \mathrm{mg} / \mathrm{L} \mathrm{CaCO}_{3}, 0.025 \mathrm{mg} / \mathrm{L} \mathrm{NO}_{2} ; 1.5$ ppm PO $4 ; 5 \mathrm{mg} / \mathrm{L} \mathrm{NO}_{3}$; $<0.1 \mathrm{mg} / \mathrm{L} \mathrm{NH}_{4}$ ). Embryos and larvae mediums were 100\%-renewed every two days. Larvae were fed twice a day with TetraMin ${ }^{\circledR}$ Baby (Tetra, Melle, DE) flakefood until the end of the experiment (20 dpf). During the whole experiment, organisms were maintained in a climate 
cabinet (Economic Delux, Snijders Scientific, Tilburg, NL) at $26^{\circ} \mathrm{C} \pm 0.3$ with a $12 \mathrm{~h}: 12 \mathrm{~h}$ photoperiod and $5000 \mathrm{~lx}$ white light.

The different procedures performed for phenotypic endpoint assessments have been previously detailed by Barjhoux et al. (2012). Viability was checked daily in all individuals from each treatment over the experimental period and dead organisms were systematically counted and removed. Heart rate was monitored in 6- and 7-dpf embryos (five randomly selected individuals per replicate). Biometric measurements (total body length, head size and head/body length ratio) and developmental anomalies (spinal, craniofacial, ocular, cardiovascular, yolk-sac and edema) were observed in 15 randomly selected newly hatched larvae per replicate. All these observations were carried out in an air-conditioned room at $23{ }^{\circ} \mathrm{C} \pm 1$ using a stereomicroscope (MZ75, Leica

Microsystem) equipped with a color CCD camera (Leica DFC 420C) and cold-light source

(Intralux ${ }^{\circledR} 4100$, Volpi AG), connected to an image analysis software program (Leica Application Suite v2.8.1.).

\subsection{Comet assay}

Genotoxicity of sediments was evaluated on 2 dph-larvae (five per pool sampled in each replicate) using the comet assay. Cell dissociation and comet assay procedures were carried out following the protocol described by Morin et al. (2011). Briefly, pools of larvae were digested in a MEM-Collagenase IV $0.125 \%(\mathrm{w} / \mathrm{v})$ medium, and cell viability was checked using a trypan blue exclusion test (only cell suspensions with viability superior to $80 \%$ were used). Once embedded in a 1\%-low melting point agarose gel, cells were lysed and immerged in an electrophoresis buffer (0.3 M NaOH, 1 mM EDTA; $\mathrm{pH}>13$ ) for 15 min to allow DNA unwinding. Then, electrophoresis was carried out at $25 \mathrm{~V}, 300 \mathrm{~mA}$ for $15 \mathrm{~min}$. Ethidium bromide (20 mg/L) was used as DNA fluorescent tag and coded-slides were blind-analyzed for 75 nuclei per gel (two gels per experimental replicate) using an Olympus epi-fluorescent microscope (400x 
magnification) equipped with a grayscale CCD camera (Zeiss, DE) and the Komet 5.5 software program (Kinetic Imaging, Liverpool, UK). As recommended by Hartmann et al. (2003), the Tail DNA (percentage of DNA which migrates from the nucleus i.e. the head of the comet) was selected to measure the rate of DNA damage. Heavily DNA-damaged nuclei displaying a small or inexistent head and a large diffuse tail, also known as 'hedgehog' cells, were not taken into account in the comet measurement, according to the recommendations of Kumaravel et al. (2009). However, the percentage of 'hedgehog' cells, which have been reported as apoptotic or necrotic cells (Olive and Banath, 1995), was visually scored on a total of 100 cells per gel.

\subsection{Statistical analysis}

The data is expressed as mean \pm standard deviation (SD). Statistical analyses were conducted using Statistica 7.1 software (Statsoft, Maisons-Alfort, FR). Results were initially tested for normality (Shapiro-Wilk's test on residues with 1\% risk) and homoscedasticity (BrownForsythe's test, 5\% risk). Afterwards, significant differences between treatments were tested with a one-way or two-way ANOVA analysis followed by a post-hoc Tukey's test $(p<0.05)$.

The existence and significance of relationships between parameters were determined using parametric Pearson's product-moment correlation (Pearson $r$ ) analysis. Principal component analysis (PCA) on standardized data was used to obtain an overview of the spatial distribution pattern of the different studied parameters (physico-chemical and toxicological endpoints) and to assess the relative implication of these factors in sediment discrimination. Only principal component axes with an eigenvalue superior to the mean of the eigenvalues were considered. Variables and cases contributions were considered as significant when superior to the mean of contributions (i.e. $>1 / n b$. of variables or cases). Factor-variable correlations (equals to factor coordinate of the variable for the considered component) were considered as significant when above 0.6 . We considered that a principal component was significantly loaded by variables 
showing both significant contribution and factor-variable correlation coefficient. Key values obtained from the different PCA conducted in this study are given in Supporting Information (SI) (Tables i to v).

\section{Results}

\subsection{Sediment physico-chemistry}

The physico-chemical characteristics of the sediments from the Lot-Garonne continuum are summarized in Table 1. Principal component analysis and Pearson's coefficient calculations were performed on POC content, $\mathrm{NH}_{4}$ concentration and the percentage of fine particles $(<63 \mu \mathrm{m})$ (SI Fig. $i$ and Table i). In agreement with the inter-correlation of sediment physicochemical endpoints, the first component of the PCA explained almost $90 \%$ of the total variability. As a result, the factor scores of cases on this first component were used to define a new synthetic variable called 'GPN' equal to the minus factor score value obtained for each station (SI Table i). This GPN variable was used in subsequent PCA analysis as an integrative representation of the three physico-chemical characteristics of each sediment: stations showing a positive GPN value are associated to high fine particles $<63 \mu \mathrm{m}, \mathrm{NH}_{4}$ and POC contents (Bdx and LR) and, on the contrary, sites with negative GPN value are associated to low fine particles $<63 \mu \mathrm{m}, \mathrm{NH}_{4}$ and POC contents (Mrc, Jo and LT). GPN value for Bo sediment was close to 0 as this sediment showed intermediate physico-chemical characteristics (SI Fig. i and Table i).

\subsection{Organic pollutant distribution}

A comprehensive analysis of organic pollutants was conducted in sediment from each station and is summarized in Table 1. Organic contamination of sediments was nearly exclusively attributable to PAHs as the presence of organohalogenated compounds was very marginal at all 
stations. The highest concentrations of PAHs were measured for Jo and LT sites, with a total PAH concentration over $25 \mu \mathrm{g} / \mathrm{g} \mathrm{dw}$. The others sites were clearly less impacted by organic contaminants with a total load around $1 \mu \mathrm{g} / \mathrm{g}$ dw for Bdx, LR and Bo and close to $15 \mathrm{ng} / \mathrm{g}$ dw for Mrc.

The PCA based on organic contaminant levels gave two principal components accounting respectively for $74.5 \%$ and $25 \%$ of the variability among the data set (SI Fig. ii and Table ii ). The first principal component was significantly loaded by heavy PAHs (high molecular weight PAHs i.e. composed by four or more aromatic rings) and MPhe. In turn, the second component was significantly loaded by light PAHs (low molecular weight PAHs i.e. composed by three or fewer aromatic rings) and DBT (SI Fig. iiA). Consequently, sums of light and heavy PAHs, DBT and total MPhe concentrations (see Table 1 for the complete list of analyzed compounds) were used in further PCA as integrative variables efficiently representing organic compound distribution among the six sediments of the study.

The plot of the different sediments in the projection plan derived from the two principal components separated three groups of sites (SI Fig. iiB). The first group included Mrc, Bo, Bdx and LR stations on the right part of the plan, representing sites weakly impacted by organic contamination. Contrarily, Jo and LT projections were both situated on the left side of the plan, traducing the high organic contaminant content in these sediments. These two sites were also clearly separated from each other by the second component axis, highlighting a contamination dominated by light PAHs and heavy PAHs, respectively.

\subsection{Metallic trace element distribution}

Chemical analysis of 10 MTE carried out on the sediments from the Lot-Garonne system revealed significant metallic contamination at Bo and Jo stations, with total MTE concentrations above $3,000 \mu \mathrm{g} / \mathrm{g} \mathrm{dw}$ at each site (Table 1). The other sites were less subject to metallic 
contamination with values below $900 \mu \mathrm{g} / \mathrm{g} \mathrm{dw}$ for Bdx and LR, and lower than $400 \mu \mathrm{g} / \mathrm{g} \mathrm{dw}$ for Mrc and LT (Table 1).

347 Consistently with the strong positive inter-correlation observed between each MTE concentrations, the PCA results showed that the first principal component accounted alone for more than $80 \%$ of the variability amongst the data (SI Fig. iii and Table iii). This axis was

350 significantly negatively loaded by each individual MTE concentrations. Hence, the sum of MTE was used in further analysis as an integrative endpoint representing metallic contamination distribution among studied sediments. The plot of case factor coordinates for different sites on the first principal component separated three groups of sites: Jo and Bo sites (first group) characterized by high concentrations of MTE, Bdx and LR stations (second group) with an intermediate position, and Mrc and LT (third group) associated to low MTE contamination level.

\subsection{Global toxicity prediction based on contaminant analysis}

Concentrations of contaminants were compared to the threshold effect concentration (TEC) and probable effect concentration (PEC) established as consensus-based freshwater sediment quality guidelines (MacDonald et al., 2000). These thresholds were respectively intended to identify chemical concentrations below which harmful effects on organisms are unexpected, and above which these effects are expected to occur frequently. Concerning organic contaminants, both TEC and PEC values established for total PAH concentration were substantially exceeded for Jo and LT. Individual PAH concentrations (for which quality criteria were available) were much higher than TEC values in Jo and LT (except for naphthalene) sediments. Similarly, PEC values were also exceeded for heavy PAHs and

367 phenanthrene in LT, and for light PAHs, except naphthalene, in Jo sediments. Among the studied MTE for which PEC and TEC values were available, $\mathrm{Cd}, \mathrm{Pb}, \mathrm{Zn}$ and As 
thresholds were exceeded for all available MTE in Bo (except for $\mathrm{Cr}$ and $\mathrm{Hg}$ ) and Jo (except for $\mathrm{Cr}$ and Ni) stations. As concentrations were also above TEC value in Mrc and LR sediments. Similar observations were done for $\mathrm{Cd}$ in Bdx and LR sites.

As recommended by MacDonald et al. (2000), the overall potential toxicity of sediments was evaluated calculating PEC quotients (qPEC, equals to measured concentration divided by the PEC value of the corresponding compound). The mean of qPECs was then calculated for each station (Table 1). Sediments were predicted to be toxic when the mean qPEC value exceeded 0.5 as established by the authors. The mean qPEC value can be calculated using PEC value established for the sum of PAH concentrations (mean qPEC1) or PEC values for individual PAHs (mean qPEC2). Neither Mrc, LR nor Bdx sediments were predicted as toxic according to the calculated mean qPEC values. Whereas the mean qPEC1 was below the 0.5 -limit in LT, the mean qPEC2 for this site exceeded this threshold mainly due to some heavy PAHs showing qPEC values around 2.0 as fluoranthene, pyrene and benzo[a]anthracene. Whatever the calculation method used, mean qPEC values were both over 0.5 at Bo and Jo stations, mostly owing to qPEC values between 2.0 to 5.0 for MTE as Cd, Pd and Zn. Moreover, very high qPEC values were observed for phenanthrene and anthracene (above 5.0 and 9.0 respectively) for Jo sediment. As a result, several chemicals including several PAHs and MTE may potentially represent a threat for aquatic organisms. The ecotoxicity of the sediments from the Lot-Garonne continuum was thus evaluated using the MELAc.

\subsection{Acute toxicity and impact on embryonic development}

Dissolved oxygen measurements were performed over the 10 day-exposure of the MELAc (SI Fig. iv). The 10 day-averaged dissolved oxygen levels in Bdx and LR treatments were lower in comparison to the reference (Mrc) with values around $88 \%$. However, it must be emphasized that all the mean values and each dissolved oxygen daily measurement (data not shown) were over 
$80 \%$, thus within the concentration range recommended by OECD for fish embryo-larval stage toxicity testing (OECD, 2013).

In agreement with the good oxygenation levels, mean embryonic survival rates and hatching success were high (> 90\%) in all treatments, with no significant difference between sites (SI Table iv). Similarly, mean larval and cumulative survival rates in the Mrc reference group remained high ( $\geq 95 \%$, SI Table iv). Although statistically similar, mean values for these endpoints were quite lower in the other treatments, respectively decreasing down to $70 \%$ and $67 \%(p=0.053)$ in LR treatment (SI Table iv).

Additionally, exposure to the Garonne sediments significantly delayed embryonic development. Indeed, the mean time to hatch was around $11 \mathrm{dpf}$ in Bdx and LR when the embryonic developmental time in the reference group was below $10 \mathrm{dpf}$ in average (Fig. 2A). In the other treatments, time to hatch fluctuated around $10.3 \mathrm{dpf}$ (Fig. 2A). Medaka in ovo growth was evaluated using biometric measurements at hatching (Fig. 2B). The mean total body length and treatment was also statistically shorter than in Mrc group while it only represents a $1 \%$-decrease.

\subsection{Teratogenicity}

The potential teratogenicity of sediments was evaluated examining the presence of morphological abnormalities in each newly hatched larvae. The total percentage of abnormal larvae and the type of deformities were recorded and are summarized on Table 2. In the reference treatment (Mrc), the percentage of malformed larvae was around $13 \%$ in average with spinal and cardiovascular deformities as main types of anomalies recorded (Table 2). The percentage of malformed individuals was significantly increased in all the other treatments in comparison to reference (Table 2). The maximum mean values close to $70 \%$ or above were 
observed for LR, Bo and Jo sites and were statistically higher than for Mrc and LT sediments (Table 2). The same discrimination between sites was observed examining the occurrence of cardiovascular anomalies which were the most frequent type of deformity, impacting up to more than $60 \%$ of the larvae in Jo treatment (Table 2). These anomalies included abnormal positioning of the heart chambers (in relation to each other and to the cephalo-caudal axis) as well as heart hypo-, hyper-development, or dystrophies.

The appearance of edemas (mainly pericardial) was also significant in larvae exposed to Jo and LR sediments, affecting $15-16 \%$ of the larvae, when compared to the reference (Table 2). Spinal deformities, predominantly lordosis, kyphosis, C-shaped larvae and few scoliosis, were observed in a fifth to one quarter of the organisms exposed to Bdx, LR and Jo sediments which is significantly higher than for Mrc treatment (Table 2). Finally, yolk sac resorption defects significantly damaged nearly $16 \%$ of the larvae in Jo group whereas this pathology was absent from the reference population (Table 2).

\begin{tabular}{|c|c|c|c|c|c|c|c|}
\hline Condition & Tot. D (\%) & Ed (\%) & Sp (\%) & Cf (\%) & Oc (\%) & $\mathrm{Cv}(\%)$ & Ys (\%) \\
\hline Mrc & $12.7 \pm 5.45^{\mathrm{a}}$ & $1.28 \pm 2.22^{a}$ & $5.13 \pm 2.22^{a}$ & $0.00 \pm 0.00$ & $0.00 \pm 0.00$ & $8.89 \pm 5.54^{a}$ & $0.00 \pm 0.00^{\mathrm{a}}$ \\
\hline$B d x$ & $61.0 \pm 3.83 b c$ & $0.00 \pm 0.00^{a}$ & $22.4 \pm 7.20 \mathrm{bc}$ & $1.23 \pm 2.14$ & $0.00 \pm 0.00$ & $49.0 \pm 10.4^{b c}$ & $1.23 \pm 2.14^{\mathrm{ab}}$ \\
\hline LR & $70.0 \pm 7.96^{c}$ & $15.7 \pm 6.40^{b}$ & $23.8 \pm 5.01 \mathrm{bc}$ & $1.28 \pm 2.22$ & $1.28 \pm 2.22$ & $59.5 \pm 10.5^{c}$ & $13.1 \pm 5.80^{a b}$ \\
\hline LT & $43.6 \pm 5.57^{b}$ & $3.96 \pm 0.23^{a}$ & $13.3 \pm 2.98^{a b}$ & $6.89 \pm 8.70$ & $0.00 \pm 0.00$ & $32.9 \pm 0.77^{b}$ & $4.11 \pm 4.17^{a b}$ \\
\hline Bo & $65.2 \pm 8.58^{c}$ & $2.57 \pm 2.23^{a}$ & $11.7 \pm 4.03 \mathrm{ab}$ & $6.57 \pm 8.38$ & $1.23 \pm 2.14$ & $56.1 \pm 10.3^{c}$ & $13.0 \pm 6.23 \mathrm{ab}$ \\
\hline
\end{tabular}


438 Values represent the mean response $( \pm \mathrm{SD})$ for three replicates. Statistical analysis was performed on each endpoint independently. Different letters indicate significant differences between treatments using one-way ANOVA followed by Tukey's post-hoc test $(p<0.05)$. In bold, statistical differences with control group (Mrc).

\subsection{Cardiac activity}

Cardiac activity measurements were performed in $6 \mathrm{dpf}$ - and $7 \mathrm{dpf}$-embryos from each treatment. Results showed a significant increase of heartbeat rate in 6 dpf-embryos exposed to LR and Jo sediments in comparison to Mrc treatment (Fig. 2C). Cardiac activity acceleration in 6 dpfembryos was also close to significant threshold $(p=0.053)$ in Bdx when compared to the reference. Conversely, a significant decrease in cardiac activity was observed in 7 dpf-embryos following exposure to LT, Bo and Jo sediments when compared to Mrc (Fig. 2C). As a result, the mean heart rate was significantly $(p<0.01)$ lower at $7 \mathrm{dpf}$ than at $6 \mathrm{dpf}$ in embryos from the same treatment for LR, LT, Bo and Jo stations (Fig. 2C).

\subsection{Genotoxicity}

The potential induction of DNA damage following exposure to sediments from the Lot-Garonne system was evaluated in 2 dph-larvae using the comet assay. Basal DNA strand breaks (Tail DNA) and the percentage of 'hedgehog' cells in reference larvae were low with average values below $10 \%$ (Fig. 2D). The percentage of tail DNA slightly raised in the other treatments to reach a maximum value of $18 \%$ in average in Jo station, which was significantly different from Mrc (Fig. 2D). Likewise, the percentage of 'hedgehog' cells was quite similar (17-20\%) for Bdx, LR and Bo stations and reached maximum values of $25 \%$ and $28 \%$ in Jo and LT treatments respectively, representing a significant raise of heavily DNA damaged cells (Fig. 2D). 


\subsection{Crosslink analysis of physico-chemical characteristics of sediments and toxic} responses in medaka ELS

Principal component analysis was conducted on physico-chemical (GPN variable, dissolved oxygen concentrations), contamination (Sum of MTE, light PAHs and MPhe, DBT) and biological endpoints which included embryonic and larval survival rates, hatching success, time to hatch, cardiac activities, biometric measurements (total body length and head size), the percentage of abnormal larvae and genotoxicity endpoints (Tail DNA and 'hedgehog' cells). Results of this analysis are summarized on Fig. 3 and SI Table v.

The two principal components (PC1 and PC2) accounted respectively for $53.1 \%$ and $26.9 \%$ of variability among the data set. Thus, the resulting projection plan PC1xPC2 explained $79.9 \%$ of variability in total. Total heavy PAHs did not significantly contributed to the two principal component determination and was thus excluded from the analysis.

The first component (PC1) was significantly negatively loaded by teratogenicity and genotoxicity endpoints as well as by some organic contamination variables including total light PAHs and DBT. In its positive direction, this axis was also significantly loaded by embryonic survival, hatching success and biometric measurements (Fig. 3A and SI Table v). Moreover, significant correlations with this principal component were observed with 7 dpf -cardiac activity (positive), total metallic and MPhe contamination levels (negative). In turn, the second component axis (PC2) was significantly loaded by larval survival and dissolved oxygen level in its negative sense and positively by GPN variable, time to hatch, and $6 \mathrm{dpf}$-cardiac activity (Fig. 3A and SI Table v).

The plot of the different sites on the resulting projection plan separated four groups of sites (Fig. 3B). A first group, including Mrc station only, was located on the bottom right of the plan. This area is associated with marginal contamination level, 'good' physico-chemical properties and 
non-toxic responses. Bdx and LR stations (second group) were gathered in the upper part of the plan, principally characterized by 'bad' physico-chemical properties and specific toxic responses (according to the second component). Jo station (third group) was isolated at the bottom left of the plan. This area is associated with elevated contamination levels, 'good' physico-chemical properties and toxic responses (according to the first component only). Finally, the fourth group consisting of Bo and LT stations, occupied an intermediate position, close to the origin of the plan.

Pearson's product-moment correlation analysis was conducted on the full set of selected variables and is summarized in Table 3 and Table 4. The extent of inter-correlations among biological endpoints was first examined. Embryonic survival, hatching success and biometric measurements (total body length and head size of larvae) proved to be significantly and positively correlated with one another (Table 3). Time to hatch and larval survival showed a significant negative correlation. The percentage of abnormal larvae was positively correlated to Tail DNA and 6 dpf -cardiac activity (Table 3) as well as with the main kind of developmental correlation with biometric measurements and $7 \mathrm{dpf}$-cardiac activity $(p=0.095)$ (Table 3). Lastly, the percentage of hedgehog cells was inversely correlated to $7 \mathrm{dpf}$-cardiac activity

(Table 3 ) and especially to the percentage of cardiovascular injuries $(r=0.926 p=0.008)$ and of spinal deformities $(r=0.965 p=0.002) .7 \mathrm{dpf}$-cardiac activity showed a negative correlation with the percentage of craniofacial deformities $(r=-0.876 p=0.022)$. Examination of the relationship between biological, contamination and physico-chemical variables gave the following results. 
511 Hatching success displayed a negative correlation to DBT levels and more slightly with total

512 light PAH concentrations ( $p=0.061$, Table 3 ) with a significant correlation with phenanthrene

513

514 $534=0.036 ;$ data not shown).

coefficient around -0.7 although insignificant. Time to hatch, $6 \mathrm{dpf}$-cardiac activity and the percentage of abnormal larvae were all three negatively and significantly correlated with dissolved oxygen levels (Table 3). The two most frequent types of developmental anomalies (spinal deformities and cardiovascular anomalies) were also significantly negatively correlated with dissolved oxygen levels (Table 4). Cardiovascular injuries were also significantly correlated to $\mathrm{Mn}$ and Co levels (respective $r$-values equal to 0.85 and $0.84, p$-values equal to 0.032 and 0.037; data not shown). Time to hatch was also inversely correlated to GPN variable. Total body length of larvae showed a negative significant correlation with total MTE content, and more precisely with $\mathrm{Ag}, \mathrm{Cd}, \mathrm{Cu}, \mathrm{Pb}$ and $\mathrm{Zn}$ ( $r$-values between -0.85 to $-0.94 ; p<0.05$; data not shown). This endpoint was also inversely correlated with light PAH concentration (Table 3) including naphthalene, acenaphthene, fluorene and anthracene ( $r$-values between -0.81 to $-0.89 ; p<0.05$; data not shown). Tail DNA was not significantly correlated to any physico-chemical or contamination variables despite correlation coefficients varying between 0.75 and 0.78 with several of them. The percentage of hedgehog cells proved to be positively correlated to the total concentrations of MPhe and organic contaminants and, to a lesser extent to heavy PAHs $(p=0.059)$. When analyzed in detail, this genotoxicity endpoint showed significant positive correlation with fluoranthene and triphenylene+chrysene concentrations ( $r$-values equal to 0.82 ; $p<0.05)$. Finally, craniofacial deformities proved to be significantly correlated with MPhe and total organic compounds whereas yolk sac resorption defects showed a positive correlation with total metallic contamination (Table 4), more specifically with Mn concentrations ( $r=0.84$ with $p$ 
Table 3 Pearson's correlation coefficients between physico-chemical, contamination and biological endpoints

\begin{tabular}{|c|c|c|c|c|c|c|c|c|c|c|c|}
\hline & ES & LS & HS & $\mathrm{TH}$ & CA 6dpf & CA 7dpf & $\mathrm{BL}$ & $\mathrm{HSz}$ & Tot. D & Tail DNA & H. cells \\
\hline ES & - & 0.400 & $0.986^{\star * \star}$ & 0.096 & -0.291 & 0.522 & $0.821^{*}$ & $0.833^{\star}$ & -0.348 & -0.676 & -0.604 \\
\hline LS & 0.400 & - & 0.460 & $-0.856^{\star}$ & -0.795 & 0.281 & 0.129 & 0.539 & -0.653 & -0.436 & -0.486 \\
\hline $\mathrm{HS}$ & $0.986^{\star \star \star}$ & 0.460 & - & 0.010 & -0.411 & 0.538 & $0.840^{\star}$ & $0.849^{\star}$ & -0.449 & -0.767 & -0.671 \\
\hline $\mathrm{TH}$ & 0.096 & $-0.856^{\star}$ & 0.010 & - & 0.800 & -0.039 & 0.196 & -0.229 & 0.635 & 0.198 & 0.175 \\
\hline CA 6dpf & -0.291 & -0.795 & -0.411 & 0.800 & - & -0.379 & -0.385 & -0.631 & $0.940^{\star \star}$ & 0.724 & 0.499 \\
\hline CA 7dpf & 0.522 & 0.281 & 0.538 & -0.039 & -0.379 & - & 0.615 & 0.584 & -0.615 & -0.736 & $-0.833^{\star}$ \\
\hline $\mathrm{BL}$ & $0.821^{\star}$ & 0.129 & $0.840^{\star}$ & 0.196 & -0.385 & 0.615 & - & $0.868^{\star}$ & -0.553 & $-0.840^{\star}$ & -0.526 \\
\hline $\mathrm{HSz}$ & $0.833^{*}$ & 0.539 & $0.849^{*}$ & -0.229 & -0.631 & 0.584 & $0.868^{\star}$ & - & -0.726 & -0.788 & -0.497 \\
\hline Tot. D & -0.348 & -0.653 & -0.449 & 0.635 & $0.940^{\star}$ & -0.615 & -0.553 & -0.726 & - & $0.824^{\star}$ & 0.576 \\
\hline Tail DNA & -0.676 & -0.436 & -0.767 & 0.198 & 0.724 & -0.736 & $-0.840^{\star}$ & -0.788 & $0.824^{\star}$ & - & 0.805 \\
\hline H. cells & -0.604 & -0.486 & -0.671 & 0.175 & 0.499 & $-0.833^{\star}$ & -0.526 & -0.497 & 0.576 & 0.805 & - \\
\hline $\mathrm{dO} 2$ & 0.148 & 0.737 & 0.277 & $-0.816^{\star}$ & $-0.987^{\star \star \star}$ & 0.360 & 0.294 & 0.524 & $-0.934^{\star \star}$ & -0.675 & -0.461 \\
\hline GPN & 0.202 & -0.696 & 0.154 & $0.918^{*}$ & 0.685 & 0.032 & 0.200 & -0.245 & 0.584 & 0.046 & -0.099 \\
\hline$\Sigma \mathrm{MTE}$ & -0.506 & 0.070 & -0.534 & -0.194 & 0.373 & -0.566 & $-0.903^{*}$ & -0.735 & 0.600 & 0.748 & 0.320 \\
\hline
\end{tabular}




\begin{tabular}{|c|c|c|c|c|c|c|c|c|c|c|c|}
\hline$\Sigma$ LPAHs & -0.721 & -0.110 & -0.792 & -0.192 & 0.361 & -0.286 & $-0.813^{\star}$ & -0.598 & 0.370 & 0.774 & 0.515 \\
\hline$\Sigma$ HPAHs & -0.465 & -0.176 & -0.484 & -0.181 & -0.037 & -0.498 & -0.185 & -0.047 & -0.030 & 0.367 & 0.794 \\
\hline ¿MPhe & -0.663 & -0.180 & -0.703 & -0.225 & 0.112 & -0.527 & -0.484 & -0.291 & 0.132 & 0.604 & $0.835^{\star}$ \\
\hline DBT & -0.752 & -0.135 & $-0.819 *$ & -0.215 & 0.315 & -0.366 & -0.775 & -0.551 & 0.326 & 0.776 & 0.634 \\
\hline$\Sigma O C$ & -0.689 & -0.179 & -0.738 & -0.223 & 0.157 & -0.492 & -0.541 & -0.336 & 0.167 & 0.648 & $0.814^{\star}$ \\
\hline
\end{tabular}

537 Significant coefficients are mentioned in bold and asterisks indicate the significance level $\left({ }^{*} p<0.05 ;{ }^{* *} p<0.01 ;{ }^{* * *} p<0.001\right)$.

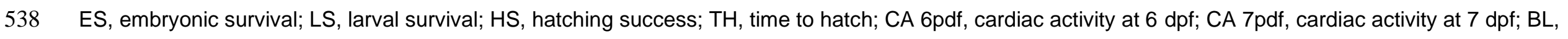
539 total body length; HSz, head size; Tot. D, percentage of deformed larvae; Tail DNA, percentage of tail DNA; H. cells, percentage of hedgehog cells; dO2,

540 dissolved oxygen. 
542 Table 4 Pearson's correlation coefficients between physico-chemical, contamination and teratogenicity

543 endpoints including edemas (Ed), spinal (Sp) and craniofacial (Cf) deformities, ocular (Oc) abnormalities,

544 cardiovascular anomalies (Cv) and yolk sac malabsorptions (Ys)

\begin{tabular}{|c|c|c|c|c|c|c|}
\hline & $\mathrm{Ed}$ & Sp & $\mathrm{Cf}$ & Oc & $\mathrm{Cv}$ & Ys \\
\hline $\mathrm{dO} 2$ & $-0,527$ & $-0,949^{\star \star *}$ & $-0,175$ & $-0,309$ & $-0,913^{\star \star}$ & $-0,552$ \\
\hline GPN & 0,343 & 0,597 & $-0,421$ & 0,661 & 0,572 & 0,275 \\
\hline$\Sigma \mathrm{MTE}$ & 0,361 & 0,274 & 0,666 & 0,271 & 0,651 & $0,797^{*}$ \\
\hline$\Sigma$ LPAHs & 0,583 & 0,457 & 0,638 & $-0,366$ & 0,397 & 0,553 \\
\hline$\Sigma$ HPAHs & 0,080 & 0,011 & 0,642 & $-0,435$ & $-0,075$ & $-0,017$ \\
\hline$\Sigma$ MPhe & 0,297 & 0,180 & $0,774^{\star}$ & $-0,463$ & 0,108 & 0,224 \\
\hline DBT & 0,544 & 0,411 & 0,714 & $-0,421$ & 0,341 & 0,497 \\
\hline$\Sigma O C$ & 0,352 & 0,239 & $0,771^{*}$ & $-0,487$ & 0,149 & 0,269 \\
\hline Tot. D & 0,569 & $0,838^{\star *}$ & 0,435 & 0,461 & $0,996^{\star \star \star}$ & $0,772^{*}$ \\
\hline
\end{tabular}

545 Significant coefficients are mentioned in bold and asterisks indicate the significance level $\left({ }^{*} p<0.1 ;{ }^{* *} p\right.$ $\left.546<0.05 ;{ }^{* * \star} p<0.01\right)$. 
Sediments are of major concern in environmental risk assessment strategies as they alternatively act as a sink or a source of contamination for aquatic biota. However, the heterogeneity of the matrix and the numerous interactions existing between sediment particles, pore-water and water column that can govern bioavailability of pollutants make sediment toxicity assessment a real challenge for scientists. The present study proposes an experimental evaluation of sediment toxicity using the MELAc without any extraction/treatment of sediment to get as close as possible to environmental conditions of exposure. Such bioassay is particularly relevant as it allows toxicity to be assessed for the bioavailable fraction of overall chemicals present in sediments. A limited number of sediment-contact bioassays using fish ELS have been proposed and successfully applied to sediment toxicity assessment on zebrafish, medaka and salmonids (e.g. Barhoumi et al., 2016; Bartzke et al., 2010; Hollert et al., 2003; Vehniäinen et al., 2015).

We supplemented this approach by a comprehensive analysis of physico-chemical properties and contamination levels in the studied sediments.

The six sediments collected in the Lot and Garonne Rivers were ranked according to their contamination level (using their mean qPEC value) and their toxicity (using the number of significant effects observed on Japanese medaka ELS; Table 1). Given the calculated mean qPEC values, a toxic impact was probable following exposure to LT (in relation to high heavy presence of MTE including $\mathrm{Cd}, \mathrm{Pb}$ and $\mathrm{Zn}$ ) and $\mathrm{Jo}$ (due to the same metallic pressure as in $\mathrm{Bo}$ but higher level of light PAHs such as phenanthrene and anthracene). In a way consistent with its marginal contamination, exposure to Mrc sediment did not result in either lethal or sublethal

571 noticeable effects in medaka ELS which confirmed its suitability as reference sediment for the MELAc. Likewise, exposure to the other Lot-Garonne sediments did not induce any significant 
acute toxicity but several sub-acute endpoints were modulated in comparison to the reference. As the most impacted site by POPs and MTE, Jo was expectedly classified as the most harmful sediment, according to both mean qPEC- and MELAc-based classifications. Whereas MTE and organic contaminant levels respectively in Bo and LT stations forecasted pronounced impacts on medaka ELS, exposure to these sediments only conducted to limited adverse effects, mainly affecting cardiac morphology and activity. Conversely, while the mean qPEC values calculated for Bdx and LR sites did not predict any particular toxicity (values $<0.5$, ranked $2^{\text {nd }}$ and $3^{\text {rd }}$ respectively), both sediments led to noticeable developmental defects $\left(3^{\text {rd }}\right.$ and $5^{\text {th }}$ position in the MELAc-based classification, Table 1). In view of these unexpected results, multivariate analyses were performed to clarify $(i)$ how the variability between sites could be jointly or independently explained by biotic (biological responses) and abiotic (physico-chemical parameters and contamination levels) endpoints, and (ii) how these parameters could be associated with each other.

As a first observation, no significant correlation was found between physico-chemical properties ( $<63 \mu \mathrm{m}, \mathrm{NH}_{4}$ and POC) and contamination levels (data not shown). Strikingly, a more comprehensive analysis showed a positive correlation between some organic micro-pollutants (heavy PAHs and total organic contamination level) and the size fraction $>500 \mu \mathrm{m}$ (data not shown). The highest PAH concentrations ( $>25 \mu \mathrm{g} / \mathrm{g} \mathrm{dw}$ ) were observed in LT and Jo which were also the coarsest sediments presenting low POC contents. These results are surprising as PAHs are generally associated to fine particle size fraction and/or rich organic matter content (Ghosh et al., 2000). Moreover, no such high PAH levels have been recorded in sediments from the WFD/SDAGE stations close to LT and Jo stations $(\leq 8 \mu \mathrm{g} / \mathrm{g} \mathrm{dw}$ at most for 18 PAHs analyzed; WFD/SDAGE data from the Adour-Garonne basin Water Information System, http://adourgaronne.eaufrance.fr/; 'Viviez bas', 'Clairac' and 'Casseneuil' stations) within the 2005-2013 
period. Some wide spatio-temporal variability in the sediment characteristics and point source of contamination can be at the origin of $(i)$ differences in PAH concentrations from the WFD/SDAGE data and the present study, (ii) the unexpected correlation between $>500 \mu \mathrm{m}$ grain size fraction and heavy PAH concentrations. This correlation may thus likely be a 'coincidental' association rather than a real causal relationship. The contamination profile was different between these two PAH-contaminated sediments with a predominance of heavy PAHs in LT and light PAHs in Jo stations, representing a respective 2300 -fold and 4800 -fold increase in comparison to Mrc reference site. The limited biological responses following exposure to LT sediment as regards its level of contamination can be explained by a contamination particularly marked by heavy PAHs that are known to be poorly water soluble and strongly bounded to organic matter, which may limit their bioavailability to embryos exposed to this sediment. However, the source of these unforeseen PAH contaminations remained unknown and further investigations are needed to clarify their origin. Conversely, the highest metal contents were observed in Jo and Bo sites consistently with their vicinity of the now-abandoned zinc factory in Decazeville. The metal enrichment was particularly marked for $\mathrm{Cd}, \mathrm{Zn}, \mathrm{Ag}, \mathrm{Pb}$ and $\mathrm{Cu}$ in agreement with previous works which identified these compounds as the main MTE released in the Lot-Garonne system from the former mining site (Audry et al., 2004).

These extremely high levels of metallic and PAH contamination are most likely responsible for the adverse effects observed in medaka ELS as supported by multivariate analysis results. Indeed, the first component derived from the PCA explained more than $50 \%$ of the data variability and can be interpreted as the discriminating axis for the biological responses associated to micro-pollutant contamination. According to the multivariate analysis, high pollutant contents including DBT, light PAHs, and in a quite lesser extent, MTE and MPhe were clearly associated to adverse effects such as genotoxicity, teratogenicity, acute toxicity 
623 (embryonic survival and hatching success), impairment of 7 dpf-cardiac activity and reduced body length and/or head size.

Hatching success was inversely correlated to DBT and phenanthrene concentrations. In turn, larvae body length showed similar relationship with several MTE $(\mathrm{Cd}, \mathrm{Cu}, \mathrm{Pb}, \mathrm{Zn}$ etc.) and light PAHs (naphtalene, fluorene, anthracene etc.). Reduced hatching success or growth retardation have also been reported in fish ELS exposed to DBT (Rhodes et al., 2005), PAH mixtures containing the above-mentioned compounds (Incardona et al., 2004; Sundberg et al., 2005) and MTE (Cao et al., 2009; Nguyen and Janssen, 2002). The lack of noticeable effects on hatching success in our study could be explained by a lower bioavailability of pollutants in natural sediments in comparison to laboratory studies. Moreover, growth parameters have been already identified as more sensitive than survival or hatching success in fish embryo-larval assays (Nguyen and Janssen, 2002). In agreement, the positive correlation between embryonic survival, hatching success and biometric endpoints suggests that larvae body length and head size could represent good predictors for acute toxicity as they allow a better discrimination between sites with less inter-replicate variability.

Genotoxicity endpoints were differentially correlated to contaminants. The percentage of hedgehog cells was correlated to MPhe and total organic micro-pollutant contents whereas the Tail DNA was rather associated to light PAH and MTE levels. These observations suggested that the induction of DNA strand breaks and heavily DNA damaged cells could result from the impact of various potent genotoxicants and are thus complementary markers of genotoxicity. The comet assay already proved its reliability in genotoxicity testing of PAH- and MTEcontaminated sediments or extracts in fish ELS (Kammann et al., 2004; Kosmehl et al., 2008). Interestingly, 7dpf-cardiac activity was negatively correlated to the percentage of hedgehog cells and close to significant threshold with Tail DNA, but no significant relationship was found with physico-chemical or contamination variables. Bradycardia was observed in 7 dpf-embryos 
exposed to LT, Bo and Jo sediments, respectively impacted by heavy PAHs, MTE and both MTE and light PAHs. Such reduction of heart beats has been reported in fish ELS exposed to PAHs (Incardona et al., 2004), MTE such as Cd and As (Cao et al., 2009; Li et al., 2009) and sediment organic extracts (Hallare et al., 2005). We could thus hypothesize that the inhibition of 7dpfcardiac activity in the present study is the result of PAHs and/or MTE contamination depending on the considered sediment but with a non-linear relationship to the concentration levels.

While contamination levels could easily explain hazardous effects reported in medaka ELS following exposure to the most contaminated stations, sediments from Bdx and LR stations were not supposed to induce any harmful responses according to their level of contamination. Actually these sediments conducted to non-negligible deleterious effects in exposed organisms, especially in embryos and larvae exposed to LR sediment which exhibited a toxicity spectrum almost as broad as for Jo station. Höss et al. (2010) also reported some toxic responses in several model organisms including fish embryos exposed to environmental sediments with mean qPEC values below 0.3 and qualified as lowly to moderately contaminated. The authors stated that even if a chemical pollution-mediated impact could not be excluded in the case of certain sediments, several geochemical inherent properties could also influence the response of various test organisms exposed to native sediments. Many physico-chemical characteristics, such as organic matter content, ammonia, particle grain size and dissolved oxygen at the water-sediment interface are known to govern bioavailability of sediment-bound chemicals and/or act as confounding factors in toxicity testing procedures (Chapman and Wang, 2001). Our results consistent with these observations - strongly suggest that the physico-chemical status of sediments could drive the emergence of some of the toxic effects recorded during the MELAc. In fact, the second component derived from the PCA analysis (27\% of the total variability) associated 'bad' physico-chemical properties (i.e. high contents of $<63 \mu \mathrm{m}$ particles, $\mathrm{NH}_{4}$ and 
POC illustrated by the GPN variable, and low dissolved oxygen levels) to specific toxic responses including delayed hatching events, an increased 6 dpf-cardiac activity and low larval survival rates. Among these biological effects, a strong correlation was shown between time to hatch and larval survival. Considering that larval survival failed to show statistically significant modulations during the experiment whereas time to hatch did so, this latter endpoint could be considered as more sensitive and as a potential predictor for acute effects at the larval stage. However, delayed hatching time also proved to be strongly associated to low GPN and dissolved oxygen values. Strong hypoxic conditions (around 1 or $2 \mathrm{mg} / \mathrm{L}$ i.e. 12-24\% sat.) may rapidly arise at the water-sediment interface and within the $500 \mu$ m-layer just above during sedimentcontact bioassays using natural whole sediments rich in organic matter, even if dissolved oxygen concentration in the test medium remained high (Strecker et al., 2011). As this zone is exactly where embryos develop during the bioassay, this local oxygen depletion could result in toxic effects overlaying chemical expected impacts (e.g. developmental retardations, spinal curvatures, altered heart beats, vascular system development impairment, reduced larval length etc.), directly or via synergetic interactions with contaminants, thus leading to biased results in whole sediment testing (Hassell et al., 2008; Küster and Altenburger, 2008; Strecker et al., 2011). High organic content in sediment could also amplify hypoxia phenomenon by activating on microbial aerobic degradation of organic matter (Braunbeck et al., 2005; Strecker et al., 2011). Similarly, fine particles can stick onto the egg chorion and cover its micropores, disrupting oxygen supply to embryos and causing physiological and morphological impacts as well as hypoxia (Kemp et al., 2011). Fine particles remobilization and/or organic matter degradation could also increase the bioavailability, and thus the toxic effects of contaminants (Bartzke et al., 2010; Chapman and Wang, 2001; Kemp et al., 2011).

LR and Bdx sites were clearly discriminated from the others with regard to the second component axis which indicates that the toxic effects induced by these sediments are more likely 
related to their 'bad' physico-chemicals characteristics than to their contamination levels. The toxicity spectrum observed in medaka ELS exposed to these sediments (delayed hatching, cardiac activity modulation, cardiovascular anomalies, spinal deformities and edemas) considerably overlaps the one induced by hypoxia or fine particles, as described above.

However, it cannot be completely excluded that these biological responses are the result of additive or synergetic interactions between the physico-chemical components and the micropollutant contamination. Moreover, it must be kept in mind that sediment chemical analysis is never exhaustive and that hazardous pollutants - not analyzed here - could play a major role in the above-mentioned adverse effects.

The developmental impairments observed in organisms exposed to LR were very similar to those observed for Jo sediment, whose toxic effects were associated to contaminants levels according to the PCA results. On one hand, it could be interpreted as supporting the above-mentioned hypothesis of the increased toxicity of pollutants with 'bad' physico-chemical properties of sediment. On the other hand, similarities between the two teratogenicity spectra could indicate the non-specificity of the observed deformities. When the correlation matrix between physicochemical characteristics, contamination levels and developmental impairments is examined, cardiovascular and spinal anomalies proved to be strongly inversely correlated to dissolved oxygen levels. As these deformities were the most commonly observed in exposed larvae, the percentage of abnormal larvae was also negatively correlated to the oxygenation level. However, certain type of less frequent developmental abnormalities proved to be associated to contamination variables. Craniofacial deformities were correlated to organic contaminant levels whereas yolk sac malabsorptions and cardiovascular injuries were associated to metal content. These observations explained the intermediate position of the percentage of abnormal larvae between the two principal component axes albeit it proved to be more strongly associated to the first component traducing the biological impacts of pollutants. 
Another unexpected result was the differential modulation of embryo cardiac activity at $6 \mathrm{dpf}$ (tachycardia) and at $7 \mathrm{dpf}$ (bradycardia). Such responses have been already reported in medaka embryos exposed to Cd-spiked sediments (Barjhoux et al., 2016). The authors also reported a positive correlation between $6 \mathrm{dpf-cardiac}$ activity and cardiovascular injuries. They hypothesized that tachycardia at 6 dpf may be a first stress response and could be considered as an early marker of general injuries in exposed embryos whereas bradycardia at $7 \mathrm{dpf}$ could likely reflect particular effect of the tested compound. These hypotheses are supported by the results of the present work where (i) $7 \mathrm{dpf-cardiac}$ activity mainly contributed to the first component associating specific toxic responses to sediment contamination levels, and was correlated to craniofacial deformities and hedgehog cells, themselves correlated to several contaminants, (ii) 6 dpf-cardiac activity significantly contributed to the second component traducing the biological responses associated to physico-chemical characteristics of sediments and was correlated to nonspecific injuries such as the percentage of deformed larvae, cardiovascular injuries and spinal deformities. However, the underlying mechanisms and physiological repercussions of such modulation as well as the kinetics of these responses have to be clarified in further studies. It must be also emphasized that the correlations were calculated based on a limited number of sites including two 'particular cases' that LR and LT sediments are considering the mismatch between their contamination levels and the biological responses they induced.

To summarize, in the present study, more than a half of inter-site variability is explained by sediment contamination status and associated toxic impacts. Nonetheless, a non-negligible part of the toxicity can also be explained by the physico-chemical characteristics of sediments such as fine particle and POC contents and dissolved oxygen levels. The second component axis is thus extremely important in the conclusion drawn in terms of toxicity as it identified sediments whose inherent properties are inappropriate for medaka embryonic development and the biological 
markers that are more likely related to these 'bad' physico-chemical characteristics than to contamination levels. Depending on the position of each site in the component projection plan, we might conclude that Jo, Bo, LT and Mrc sediments represented adequate substrates for medaka ELS development and that the biological responses observed following exposure to these matrixes could be mainly interpreted in terms of contamination impacts. As a result, Mrc confirmed its reliability as a reference site whereas Jo station proved to be the more problematic site from the studied area with high levels of MTE and light PAHs, and a wide spectrum of toxic responses. Bo and LT occupied an intermediate position indicating that they induced only few impacts in exposed organisms despite their non-negligible respective contamination in MTE and heavy PAHs probably traducing a limited contaminant bioavailability in these sediments. On the contrary, LR and Bdx sediments induced unexpected developmental impairments in medaka ELS when considering their contamination status. The toxic responses observed (including delayed time to hatch, reduced head size, induction of edemas, spinal and cardio-vascular deformities) had to be carefully interpreted as they are more likely the result of sediments 'bad' physicochemical properties (high organic content and fine particle fraction, reduced dissolved oxygen). Overall results clearly highlight the importance, relevance and complementarity of a biological and chemical combined approach in sediment toxicity assessments. On one hand in vivo toxicity testing using whole sediments such as the MELAc allows a more realistic toxicity evaluation since it integrates the total bioavailable fraction present in the sample which is directly translated as biological responses. One the other hand, physico-chemical analysis, as comprehensive as possible (i.e. including sediment matrix characteristics and pollutants levels), enables to crosslink biological responses to chemical data in order to $(i)$ pinpoint contaminants (or class of chemicals) responsible for the observed toxic effects and (ii) potentially identify some 'false positive' results due to confounding factors as some intrinsic physico-chemical properties of natural sediments. 


\section{Conclusion}

The present study proposes to widen the use of the MELAc to toxicity assessment of environmentally multi-contaminated sediments as it allows the investigation of the impact of the whole bioavailable fraction of chemicals bounded to sediment particles, with limited handling of the matrix.

According to the results of multivariate and correlation analyses, we could identify markers that are more reliable for toxicity evaluation thanks to their higher sensitivity to micro-pollutants and lower sensitivity to physico-chemical properties of the sediment. In the present study, it appeared that biometric measurements, genotoxicity endpoints, hatching success, embryonic survival, cardiac activity at $7 \mathrm{dpf}$, and some particular developmental impairments such as craniofacial deformities and yolk sac malabsorption, were the most appropriate and specific markers of pollutant-induced toxicity. Conversely, time to hatch, cardio-vascular and spinal deformities, cardiac activity at $6 \mathrm{dpf}$ and larval survival (due to its correlation to time to hatch) might be carefully interpreted as they proved to be correlated to physico-chemical properties of sediment and dissolved oxygen level. These observations once again highlight the extreme importance of the measurement of some critical endpoints such as oxygenation level, organic matter content and fine particle fraction in natural sediments as potential confounding factors in sedimentcontact bioassays.

Nonetheless, the present study demonstrates the relevance and the applicability of the MELAc and associated biomarkers to the evaluation of the toxicity of multi-contaminated and complex matrixes as sediments. Such an approach could be efficiently integrated to a battery of tests on various phyla and trophic levels as a meaningful tool to assess the toxicity of complex environmental matrix in an environment risk assessment strategy. This work also illustrated the importance and the appropriateness of a toxicity assessment strategy combining both biological 
and physico-chemicals analyses to avoid misinterpretation of the results obtained from one or the other approach.

\section{Acknowledgments}

801 This study was supported by the Aquitaine region and the University of Bordeaux. Iris Barjhoux

802 received a PhD fellowship from the Ministère de l'Enseignement Supérieur et de la Recherche

803 (France). The authors acknowledge Michel Cremer, Henri Etcheber and Gérard Clabaud

804 (Bordeaux University, EPOC UMR CNRS 5805) for their involvement in sediment physico-

805 chemical analyses. They also thank James Emery for providing English proofreading services.

806 


\section{References}

808

809

810

811

Ahlf, W., Hollert, H., Neumann-Hensel, H., Ricking, M., 2002. A guidance for the assessment and evaluation of sediment quality: A German approach based on ecotoxicological and chemical measurements. J. Soils Sediments. 2, 37-42. http://dx.doi.org/10.1007/BF02991249.

Arini, A., Feurtet-Mazel, A., Morin, S., Maury-Brachet, R., Coste, M., Delmas, F., 2012. Remediation of a watershed contaminated by heavy metals: A 2-year field biomonitoring of periphytic biofilms. Sci. Total Environ. 425, 242-253. http://dx.doi.org/10.1016/j.scitotenv.2012.02.067.

Arini, A., Baudrimont, M., Feurtet-Mazel, A., Coynel, A., Blanc, G., Coste, M., Delmas, F., 2011. Comparison of periphytic biofilm and filter-feeding bivalve metal bioaccumulation $(\mathrm{Cd}$ and $\mathrm{Zn})$ to monitor hydrosystem restoration after industrial remediation: a year of biomonitoring. J. Environ. Monit. 13, 3386-3398. http://dx.doi.org/10.1039/c1em10581g.

Audry, S., Grosbois, C., Bril, H., Schäfer, J., Kierczak, J., Blanc, G., 2010. Post-depositional redistribution of trace metals in reservoir sediments of a mining/smelting-impacted watershed (the Lot River, SW France). Appl. Geochem. 25, 778-794. http://dx.doi.org/10.1016/j.apgeochem.2010.02.009.

Audry, S., Schäfer, J., Blanc, G., Bossy, C., Lavaux, G., 2004. Anthropogenic components of heavy metal $(\mathrm{Cd}, \mathrm{Zn}, \mathrm{Cu}, \mathrm{Pb})$ budgets in the Lot-Garonne fluvial system (France). Appl. Geochem. 19, 769-786. http://dx.doi.org/10.1016/j.apgeochem.2003.10.002.

Barhoumi, B., Clérandeau, C., Landi, L., Pichon, A., Le Bihanic, F., Poirier, D., Anschutz, P., Budzinski, H., Driss, M. R., Cachot, J., 2016. Assessing the toxicity of sediments using the 

medaka embryo-larval assay and 2 other bioassays. Environ. Toxicol. Chem. 35, 22702280. http://dx.doi.org/10.1002/etc.3388.

Barjhoux, I., Gonzalez, P., Baudrimont, M., Cachot, J., 2016. Molecular and phenotypic responses of Japanese medaka (Oryzias latipes) early life stages to environmental concentrations of cadmium in sediment. Environ. Sci. Pollut. Res. 23, 17969-17981. http://dx.doi.org/10.1007/s11356-016-6995-4.

Barjhoux, I., Cachot, J., Gonzalez, P., Budzinski, H., Le Menach, K., Landi, L., Morin, B., Baudrimont, M., 2014. Transcriptional responses and embryotoxic effects induced by pyrene and methylpyrene in Japanese medaka (Oryzias latipes) early life stages exposed to spiked sediments. Environ. Sci. Pollut. Res. 21, 13850-13866. http://dx.doi.org/10.1007/s11356-014-2895-7.

Barjhoux, I., Baudrimont, M., Morin, B., Landi, L., Gonzalez, P., Cachot, J., 2012. Effects of copper and cadmium spiked-sediments on embryonic development of Japanese medaka (Oryzias latipes). Ecotoxicol. Environ. Saf. 79, 272-282.

http://dx.doi.org/10.1016/j.ecoenv.2012.01.011.

Bartzke, M., Delov, V., Stahlschmidt-Allner, P., Allner, B., Oehlmann, J., 2010. Integrating the fish embryo toxicity test as triad element for sediment toxicity assessment based on the Water Framework Directive approach. J. Soils Sediments. 10, 389-399. http://dx.doi.org/10.1007/s11368-009-0170-1.

Baudrimont, M., Schäfer, J., Marie, V., Maury-Brachet, R., Bossy, C., Boudou, A., Blanc, G., 2005. Geochemical survey and metal bioaccumulation of three bivalve species (Crassostrea gigas, Cerastoderma edule and Ruditapes philippinarum) in the Nord Médoc 

salt marshes (Gironde estuary, France). Sci. Total Environ. 337, 265-280. http://dx.doi.org/10.1016/j.scitotenv.2004.07.009.

Braunbeck, T., Böttcher, M., Hollert, H., Kosmehl, T., Lammer, E., Leist, E., Rudolf, M., Seitz, N., 2005. Towards an alternative for the acute fish LC50 test in chemical assessment: The fish embryo toxicity test goes multi-species - An update. Altex. 22, 87-102.

Burton Jr, G. A., 1991. Assessing the toxicity of freshwater sediments. Environ. Toxicol. Chem. 10, 1585-1627. http://dx.doi.org/10.1002/etc.5620101204.

Cachot, J., Law, M., Pottier, D., Peluhet, L., Norris, M., Budzinski, H., Winn, R., 2007. Characterization of toxic effects of sediment-associated organic pollutants using the $\lambda$ transgenic medaka. Environ. Sci. Technol. 41, 7830-7836. http://dx.doi.org/10.1021/es071082v.

Cao, L., Huang, W., Shan, X., Xiao, Z., Wang, Q., Dou, S., 2009. Cadmium toxicity to embryonic-larval development and survival in red sea bream Pagrus major. Ecotoxicol. Environ. Saf. 72, 1966-1974. http://dx.doi.org/10.1016/j.ecoenv.2009.06.002.

Chapman, P. M., Wang, F., 2001. Assessing sediment contamination in estuaries. Environ. Toxicol. Chem. 20, 3-22. http://dx.doi.org/10.1002/etc.5620200102.

Devier, M. H., Augagneur, S., Budzinski, H., Le Menach, K., Mora, P., Narbonne, J. F., Garrigues, P., 2005. One-year monitoring survey of organic compounds (PAHs, PCBs, TBT), heavy metals and biomarkers in blue mussels from the Arcachon Bay, France. J. Environ. Monit. 7, 224-240. http://dx.doi.org/10.1039/b409577d. 
EC, 2010. Directive 2010/63/EC of the European Parliament and of the Council of 22 September 2010 on the protection of animals used for scientific purposes. Off. J. Eur. Parliam. L 276, 33-80.

Etcheber, H., Relexans, J. C., Beliard, M., Weber, O., Buscail, R., Heussner, S., 1999. Distribution and quality of sedimentary organic matter on the Aquitanian margin (Bay of Biscay). Deep Sea Res. Part II Top. Stud. Oceanogr. 46, 2249-2288. http://dx.doi.org/10.1016/s0967-0645(99)00062-4.

Fent, K., 2004. Ecotoxicological effects at contaminated sites. Toxicology. 205, 223-240. http://dx.doi.org/10.1016/j.tox.2004.06.060.

Ghosh, U., Gillette, J. S., Luthy, R. G., Zare, R. N., 2000. Microscale location, characterization and association of polycyclic aromatic hydrocarbons on harbor sediment particles. Environ. Sci. Technol. 34, 1729-1736. http://dx.doi.org/10.1021/es991032t.

Grasshoff, K., Johanssen, H., 1972. A new sensitive and direct method for the determination of ammonia in sea water. J. Cons. perm. int. Explor. 34, 516-521.

Hallare, A. V., Kosmehl, T., Schulze, T., Hollert, H., Köhler, H. R., Triebskorn, R., 2005. Assessing contamination levels of Laguna Lake sediments (Philippines) using a contact assay with zebrafish (Danio rerio) embryos. Sci. Total Environ. 347, 254-271. http://dx.doi.org/10.1016/j.scitotenv.2004.12.002.

Hartmann, A., Agurell, E., Beevers, C., Brendler-Schwaab, S., Burlinson, B., Clay, P., Collins, A., Smith, A., Speit, G., Thybaud, V., Tice, R. R., 2003. Recommendations for conducting 

the in vivo alkaline Comet assay. Mutagenesis. 18, 45-51. http://dx.doi.org/10.1093/mutage/18.1.45.

Hassell, K. L., Coutin, P. C., Nugegoda, D., 2008. Hypoxia impairs embryo development and survival in black bream (Acanthopagrus butcheri). Mar. Pollut. Bull. 57, 302-306. http://dx.doi.org/10.1016/j.marpolbul.2008.02.045.

Hollert, H., Keiter, S., König, N., Rudolf, M., Ulrich, M., Braunbeck, T., 2003. A new sediment contact assay to assess particle-bound pollutants using zebrafish (Danio rerio) embryos. J. Soils Sediments. 3, 197-207. http://dx.doi.org/10.1065/jss2003.09.085.

Höss, S., Ahlf, W., Fahnenstich, C., Gilberg, D., Hollert, H., Melbye, K., Meller, M., HammersWirtz, M., Heininger, P., Neumann-Hensel, H., Ottermanns, R., Ratte, H. T., Seiler, T. B., Spira, D., Weber, J., Feiler, U., 2010. Variability of sediment-contact tests in freshwater sediments with low-level anthropogenic contamination - Determination of toxicity thresholds. Environ. Pollut. 158, 2999-3010. http://dx.doi.org/10.1016/j.envpol.2010.05.013.

Hutchinson, T. H., Solbé, J., Kloepper-Sams, P. J., 1998. Analysis of the ECETOC Aquatic Toxicity (EAT) database. III - Comparative toxicity of chemical substances to different life stages of aquatic organisms. Chemosphere. 36, 129-142. http://dx.doi.org/10.1016/s0045-6535(97)10025-x.

Incardona, J. P., Collier, T. K., Scholz, N. L., 2004. Defects in cardiac function precede morphological abnormalities in fish embryos exposed to polycyclic aromatic hydrocarbons. Toxicol. Appl. Pharmacol. 196, 191-205. http://dx.doi.org/10.1016/j.taap.2003.11.026. 
Kammann, U., Biselli, S., Hühnerfuss, H., Reineke, N., Theobald, N., Vobach, M., Wosniok, W., 2004. Genotoxic and teratogenic potential of marine sediment extracts investigated with comet assay and zebrafish test. Environ. Pollut. 132, 279-287. http://dx.doi.org/10.1016/j.envpol.2004.04.021.

Kemp, P., Sear, D., Collins, A., Naden, P., Jones, I., 2011. The impacts of fine sediment on riverine fish. Hydrol. Process. 25, 1800-1821. http://dx.doi.org/10.1002/hyp.7940.

Koroleff, F., 1969. Direct determination of ammonia in natural waters as indophenol blue. Int. Con. Explor. Sea, CM C. 9, 4.

Kosmehl, T., Hallare, A. V., Braunbeck, T., Hollert, H., 2008. DNA damage induced by genotoxicants in zebrafish (Danio rerio) embryos after contact exposure to freeze-dried sediment and sediment extracts from Laguna Lake (The Philippines) as measured by the comet assay. Mutat. Res. Genet. Toxicol. Environ. Mutagen. 650, 1-14. http://dx.doi.org/10.1016/j.mrgentox.2007.09.009.

Kosmehl, T., Hallare, A. V., Reifferscheid, G., Manz, W., Braunbeck, T., Hollert, H., 2006. A novel contact assay for testing genotoxicity of chemicals and whole sediments in zebrafish embryos. Environ. Toxicol. Chem. 25, 2097-2106. http://dx.doi.org/10.1897/05-460r.1.

Kumaravel, T. S., Vilhar, B., Faux, S. P., Jha, A. N., 2009. Comet Assay measurements: A perspective. Cell Biol. Toxicol. 25, 53-64. http://dx.doi.org/10.1007/s10565-007-9043-9.

Küster, E., Altenburger, R., 2008. Oxygen decline in biotesting of environmental samples - Is there a need for consideration in the acute zebrafish embryo assay? Environ. Toxicol. 23, 745-750. http://dx.doi.org/10.1002/tox.20377. 
Lammer, E., Carr, G. J., Wendler, K., Rawlings, J. M., Belanger, S. E., Braunbeck, T., 2009. Is the fish embryo toxicity test (FET) with the zebrafish (Danio rerio) a potential alternative for the fish acute toxicity test? Comp. Biochem. Physiol. C Toxicol. Pharmacol. 149, 196209. http://dx.doi.org/10.1016/j.cbpc.2008.11.006.

Latouche, C., 1992. La pollution par le cadmium des huîtres sauvages de l'Estuaire de la Gironde. Origine. Mécanismes responsables de la fixation du cadmium. Ichtyophysiol. Acta. 15, 139-152.

Li, D., Lu, C., Wang, J., Hu, W., Cao, Z., Sun, D., Xia, H., Ma, X., 2009. Developmental mechanisms of arsenite toxicity in zebrafish (Danio rerio) embryos. Aquat. Toxicol. 91, 229-237. http://dx.doi.org/10.1016/j.aquatox.2008.11.007.

MacDonald, D. D., Ingersoll, C. G., Berger, T. A., 2000. Development and evaluation of consensus-based sediment quality guidelines for freshwater ecosystems. Arch. Environ. Contam. Toxicol. 39, 20-31. http://dx.doi.org/10.1007/s002440010075.

Morin, B., Filatreau, J., Vicquelin, L., Barjhoux, I., Guinel, S., Leray-Forget, J., Cachot, J., 2011. Detection of DNA damage in yolk-sac larvae of the Japanese Medaka, Oryzias latipes, by the comet assay. Anal. Bioanal. Chem. 399, 2235-2242. http://dx.doi.org/10.1007/s00216$\underline{010-4602-y}$.

Nguyen, L. T. H., Janssen, C. R., 2002. Embryo-larval toxicity tests with the African catfish (Clarias gariepinus): Comparative sensitivity of endpoints. Arch. Environ. Contam. Toxicol. 42, 256-262. http://dx.doi.org/10.1007/s00244-001-0007-4. 
OECD, Test No. 210: Fish, Early-life Stage Toxicity Test. Vol. OECD Guidelines for the Testing of Chemicals, Section 2. OECD Publishing, Paris, 2013, pp. 24. http://dx.doi.org/10.1787/9789264203785-en.

Olive, P. L., Banath, J. P., 1995. Sizing highly fragmented DNA in individual apoptotic cells using the comet assay and a DNA crosslinking agent. Exp. Cell Res. 221, 19-26. http://dx.doi.org/10.1006/excr.1995.1348.

Orieux, N., Cambier, S., Gonzalez, P., Morin, B., Adam, C., Garnier-Laplace, J., Bourdineaud, J. P., 2011. Genotoxic damages in zebrafish submitted to a polymetallic gradient displayed by the Lot River (France). Ecotoxicol. Environ. Saf. 74, 974-983. http://dx.doi.org/10.1016/j.ecoenv.2011.01.008.

Rhodes, S., Farwell, A., Hewitt, M. L., MacKinnon, M., Dixon, G. D., 2005. The effects of dimethylated and alkylated polycyclic aromatic hydrocarbons on the embryonic development of the Japanese medaka. Ecotoxicol. Environ. Saf. 60, 247-258. http://dx.doi.org/10.1016/j.ecoenv.2004.08.002.

Schäfer, J., Norra, S., Klein, D., Blanc, G., 2009. Mobility of trace metals associated with urban particles exposed to natural waters of various salinities from the Gironde Estuary, France. J. Soils Sediments. 9, 374-392. http://dx.doi.org/10.1007/s11368-009-0096-7.

Strecker, R., Seiler, T. B., Hollert, H., Braunbeck, T., 2011. Oxygen requirements of zebrafish (Danio rerio) embryos in embryo toxicity tests with environmental samples. Comp. Biochem. Physiol. C Toxicol. Pharmacol. 153, 318-327. http://dx.doi.org/10.1016/j.cbpc.2010.12.002. 
Sundberg, H., Ishaq, R., Åkerman, G., Tjärnlund, U., Zebühr, Y., Linderoth, M., Broman, D., Balk, L., 2005. A bio-effect directed fractionation study for toxicological and chemical characterization of organic compounds in bottom sediment. Toxicol. Sci. 84, 63-72. http://dx.doi.org/10.1093/toxsci/kfi067.

Tapie, N., Budzinski, H., Le Ménach, K., 2008. Fast and efficient extraction methods for the analysis of polychlorinated biphenyls and polybrominated diphenyl ethers in biological matrices. Anal. Bioanal. Chem. 391, 2169-2177. http://dx.doi.org/10.1007/s00216-0082148-Z.

Vehniäinen, E.-R., Siiskonen, S., Raatikainen, M., Oikari, A. O. J., 2015. Do laboratory exposures represent field exposures? Effects of sediments contaminated by wood industry on yolk-sac fry of rainbow trout (Oncorhynchus mykiss). J. Soils Sediments. 15, 20122021. http://dx.doi.org/10.1007/s11368-015-1159-6.

Vicquelin, L., Leray-Forget, J., Peluhet, L., Le Menach, K., Deflandre, B., Anschutz, P., Etcheber, H., Morin, B., Budzinski, H., Cachot, J., 2011. A new spiked sediment assay using embryos of the Japanese medaka specifically designed for a reliable toxicity assessment of hydrophobic chemicals. Aquat. Toxicol. 105, 235-245. http://dx.doi.org/10.1016/j.aquatox.2011.06.011. 


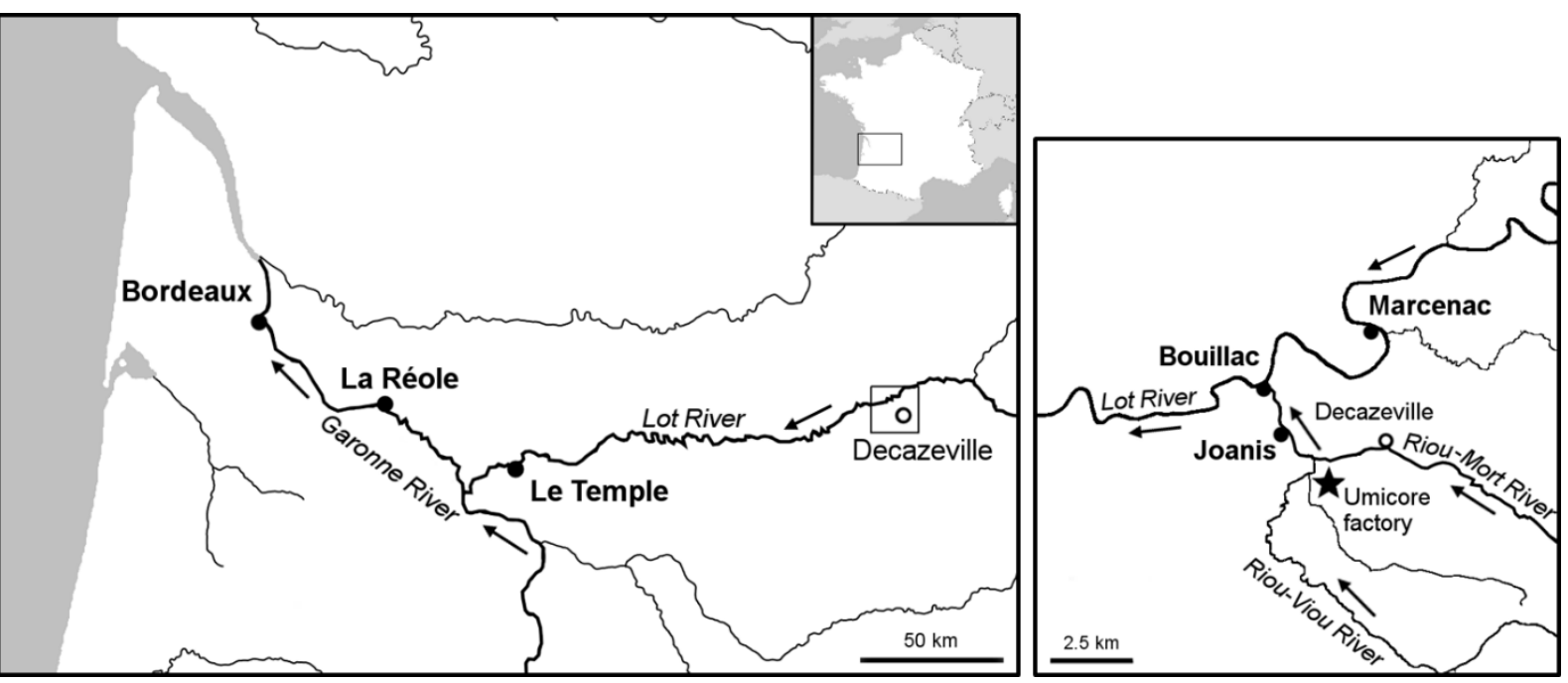

2 Fig. 1 Location of the study area and the six sampling stations (solid black dots) along the Lot-

3 Garonne system

4

5 Color is neither needed in printed nor online version. This figure could be a 1.5-column fitting image. 


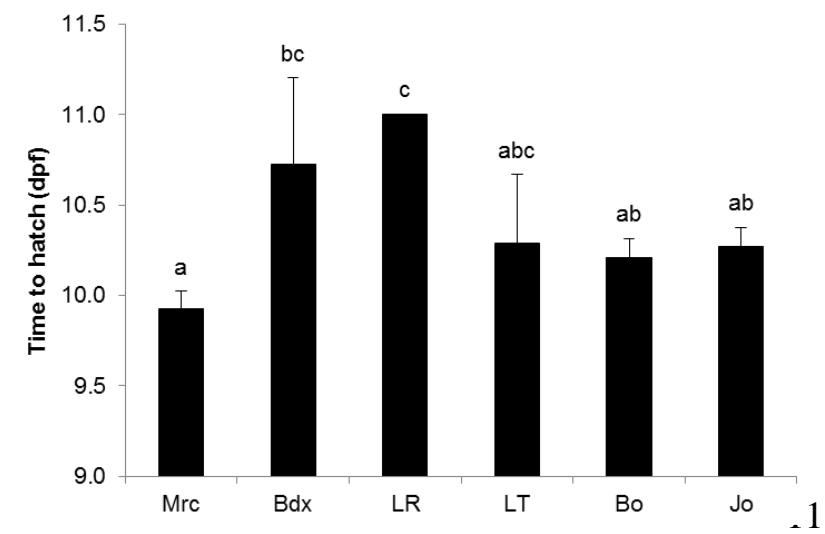

10 (B)

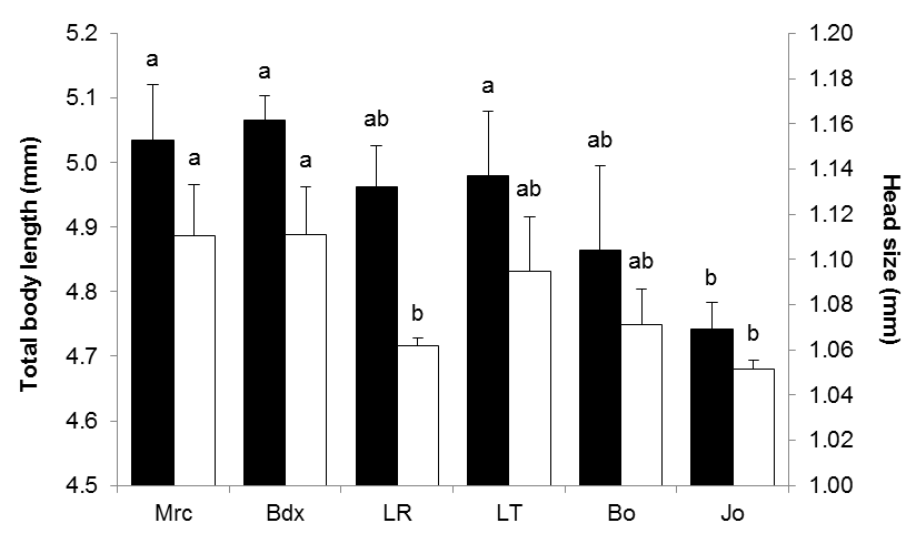

12 (D)

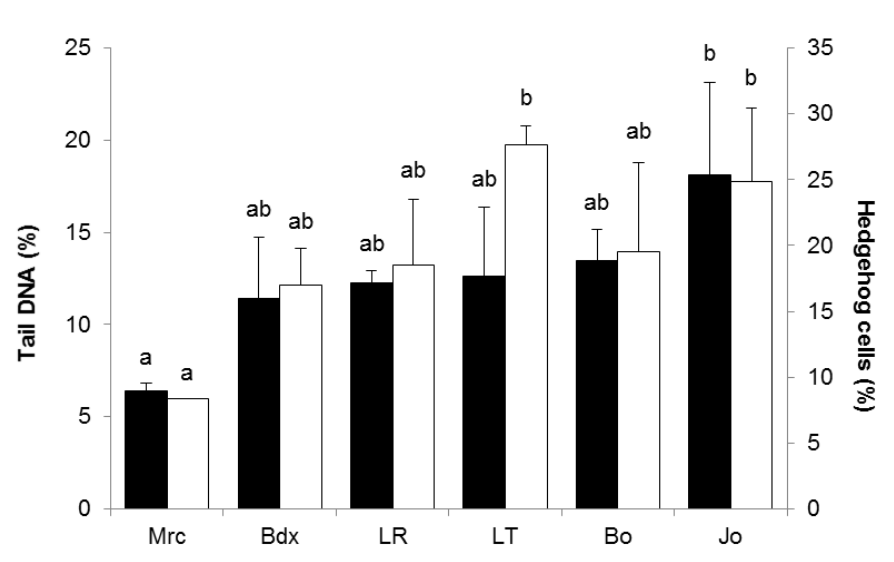

8 (C)

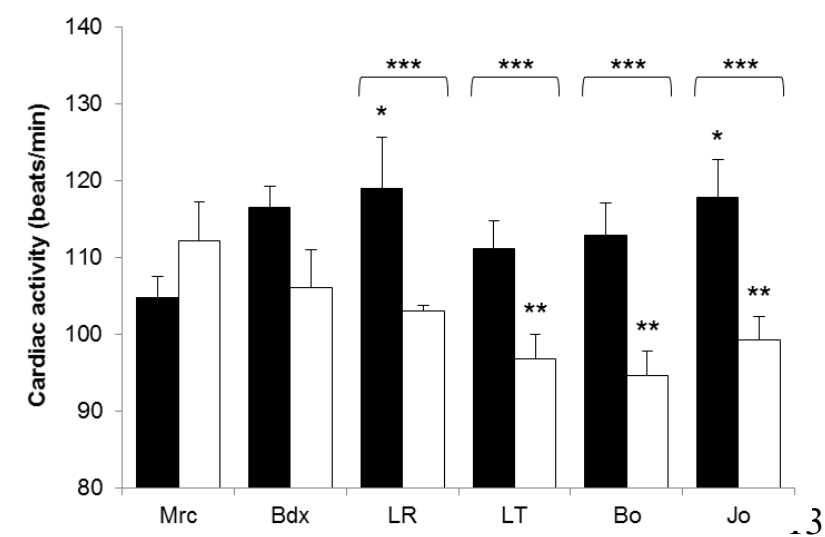

Fig. 2 Phenotypical and genotoxic effects in medaka ELS exposed to six sediments collected along the Lot-Garonne continuum: time to hatch $(A)$, biometric measurements $(B)$ at hatching (total body length (black bars, left axis) and head size (black bars, left axis), cardiac activity (C) in 6 dpf- (black bars) and 7 dpf-embryos (white bars), and DNA damage (D) in 2 dph-larvae assessed with the comet assay showing the percentage of tail DNA (black bars, left axis) and of the percentage of hedgehog cells (white bars, right axis). Values represent the mean response $( \pm S D)$ from three replicates. Different letters $(A, B$ and $D)$ indicate significant differences between treatments using one-way ANOVA followed by Tukey's post hoc test $(p<0.05)$. For cardiac activity $(C)$, statistical analysis was performed using two-way ANOVA analysis followed by Tukey's post-hoc test. One asterisk indicates a significant difference $(p<0.05)$ in comparison to Mrc treatment at $6 \mathrm{dpf}$. Two asterisks indicate a significant difference $(p<0.05)$ in comparison to Mrc treatment at $7 \mathrm{dpf}$. Three asterisks indicate a significant difference $(p<0.05)$ between $6 \mathrm{dpf}$ - and $7 \mathrm{dpf}-$ values within the same treatment

Color is neither needed in printed nor online version. This figure could be a 2-column fitting image. 


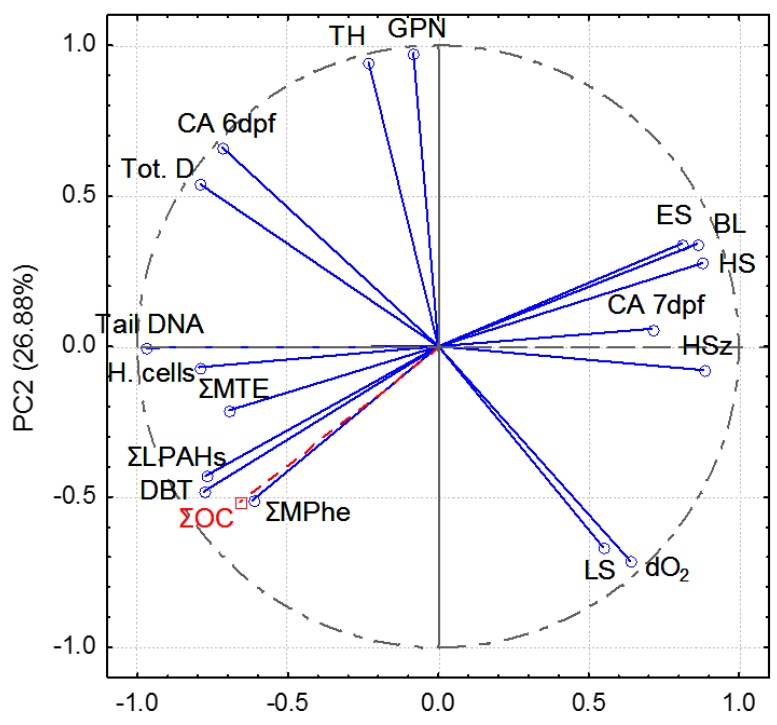

29

PC1 (53.05\%)

31

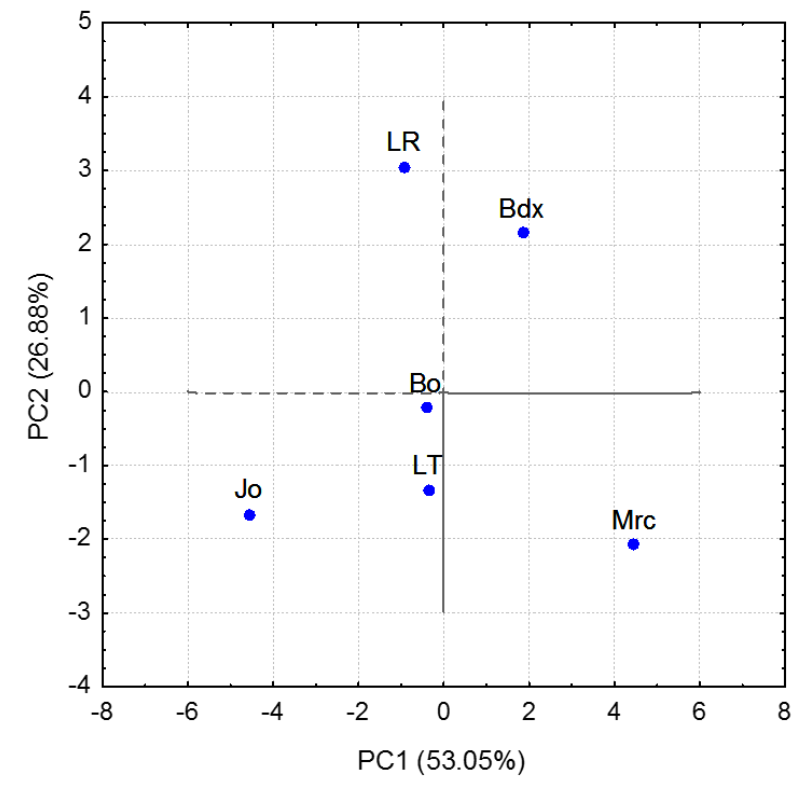

Fig. 3 PCA results for the two principal components produced by physico-chemical, contamination and biological endpoints in sediments collected along the Lot-Garonne continuum. (A) Plot of variable vectors: solid lines (ended by circles) represent active variables whereas illustrative (supplementary) variable is shown as dotted line (ended by a square). (B) Plot of case factor coordinates for the different sites. Physico-chemical variables included GPN variable (see part 3.1 for definition) and dissolved oxygen $\left(\mathrm{dO}_{2}\right)$. Contamination variables included $\Sigma$ MTE, $\Sigma$ LPAHs, $\Sigma$ MPhe, DBT and $\Sigma O C$ (see Table 1 for definition). Biological variables included embryonic (ES) and larval (LS) survival rates, hatching success (HS), time to hatch (TH), cardiac activities (CA 6dpf and 7dpf), total body length (TL), head size (HSz), the percentage of abnormal larvae (Tot. D), the percentage of Tail DNA and the percentage of hedgehog cells $(H$. cells)

Color is not needed in printed version, only in the online one. This figure could be a 1.5- or 2-column fitting image. 